\title{
A Problem Shared Is a Problem Reduced: Seeking Efficiency in the Conservation of Felids and Primates
}

\author{
David W. Macdonald ${ }^{\mathrm{a}}$ Dawn Burnham ${ }^{\mathrm{a}}$ Amy E. Hinks ${ }^{\mathrm{a}}$ \\ Richard Wrangham ${ }^{b}$ \\ a Wildlife Conservation Research Unit, Department of Zoology, University of Oxford, \\ Recanati-Kaplan Centre, Tubney, UK; b Department of Human Evolutionary Biology, \\ Harvard University, Cambridge, Mass., USA
}

\author{
Key Words \\ Threat $\cdot$ Range $\cdot$ Hotspots $\cdot$ Habitat loss $\cdot$ Fragmentation $\cdot$ Hunting $\cdot$ Bushmeat $\cdot$ \\ Persecution
}

\begin{abstract}
Threats faced by mammalian species can be grouped into one of a handful of categories, such as habitat loss, unsustainable hunting and persecution. Insofar as they face common threats, diverse species may benefit from the same conservation intervention, thereby offering efficiencies in conservation action. We explore this proposition for primates and felids by examining coarse scale overlaps in geographical distributions, using IUCN Red List assessments of the primary threats posed to each species. A global analysis of primates and felids that face common threats reveals the greatest overlap is in Central and South Asia, where up to 14 primates and felids co-occur. More than $80 \%$ of the land where at least 1 threatened species of either primate or felid occurs also contains at least one threatened species of the other taxon, yet over $60 \%$ of these grid cells containing both threatened primates and felids lie outside Conservation International's hot spots. A review of IUCN Action Plans of the threats to felids and primates strongly supports the hypothesis that they are often the same and occur in the same place. In principle, steps to conserve big cats have the potential to benefit several species of threatened primates, and vice versa.

Copyright $\odot 2013$ S. Karger AG, Basel
\end{abstract}

\section{Introduction}

Burnham et al. [2012b, this vol.] raise the question of whether some felids might serve as umbrella species to protect primates, and vice versa. In planning their conservation, it therefore becomes interesting to know not only which threats are faced

\begin{tabular}{ll}
\hline KARGER & @ 2013 S. Karger AG, Basel \\
Fax +41 61 306 12 34 & \\
$\begin{array}{l}\text { E-Mail karger@karger.ch } \\
\text { www.karger.com }\end{array}$ & $\begin{array}{l}\text { Accessible online at: } \\
\text { www.karger.com/fpr }\end{array}$
\end{tabular}

David W. Macdonald

Wildlife Conservation Research Unit

Department of Zoology

University of Oxford, Recanati-Kaplan Centre

Tubney House, Tubney OX13 5QL (UK)

E-Mail david.macdonald@zoo.ox.ac.uk 
by felids and primates, but particularly to what extent they share the same threats in the same places. If they do share similar threats, then perhaps, in line with the umbrella concept (or simply the added value of protecting several species at once), there is a better chance of achieving synergies in their conservation. Of course, a common denominator of species conservation is that it is impossible without conserving species' habitats, and Collins et al. [2011] point out that while some forest-dwelling species will be protected automatically if their forest habitat is conserved, there are other species to which this does not apply. Both felids and primates fall conspicuously into this latter category, in particular, as we go on to demonstrate, due to hunting. However, both taxa include at least some species that are charismatic, this being the second dimension on which Collins et al. [2011] classify species; 'charisma' is a human perception, but one which we know is valued [Johnson et al., 2010].

Prompted by a quest for conservation synergy through a review of the literature on threats to felids and primates, we present a preliminary test of the hypothesis that the threats faced by felids and primates are often the same and occur in the same place. Should this hypothesis be upheld, there may be commonality in the conservation actions most beneficial for both taxa which could lead to a positive, synergistic outcome in the future. We examine this hypothesis through a selected literature review, from which we derive the geographical distribution of the threats faced by the two taxa, and therefore the potential for efficiency of delivery of conservation action through tackling these together. The same question might usefully be asked about various baskets of taxa. In this special issue of Folia Primatologica on primates and predators, we have selected the Felidae because they are dedicatedly carnivorous and hence likely to live at relatively low densities moving over large home ranges. Low population densities are not only a result of felid behavioural ecology, but also increasingly due to threats that include habitat loss and fragmentation, hunting pressure and persecution for their perceived threat to humans and livestock. Despite many differences in their behaviour and life history traits, we ask whether similarities in the threats faced by felids and primates make felids candidates to be protective umbrella species for numerous primate species. The wide distributions of felids means that conservation action focussed on a single felid species may well benefit numerous primates, as well as other taxa, that fall within its range. Furthermore, as Burnham et al. [2012b, this vol.] show, there are numerous cases of predator-prey interactions between felids and primates that mean the relationships between these taxa are often entwined, such that the fate of one may impact the other. We suggest that conservation efforts that acknowledge the commonality in threats faced by cooccurring taxa, yet also the differences between these threats, have the potential to be of great impact. The quest for cross-taxa efficiency in vertebrate conservation is obviously not new, so we ask how our exploration of potential synergies between primate and felid conservation compares with the 'biodiversity hotspots' of Conservation International (CI) as a means of identifying areas to prioritise for conservation action.

\section{Methods}

Reviews can differ in the degree to which they are systematic (and are prone to bias [Roberts et al., 2006]). A systematic review follows set guidelines [Cochrane, 1972; Pullin and Stewart, 2006]. Our methodology, while not a formal systematic review, follows these guidelines in 
being thorough, systematic and transparent. For both taxa (Felidae and Primates), we selected a number of pivotal publications describing their conservation status, and methodically abstracted and tabulated the key facts regarding their biology and conservation status, as well as the threats identified as most pressing and the potential solutions for mitigating those threats.

All felid and primate species were considered. Two principal sources for felids were the IUCN/SSC Cat Action Plan [Nowell and Jackson, 1996] and Macdonald and Loveridge's [2010] Biology and Conservation of Wild Felids (and in particular, the first chapter, 'Dramatis personae: an introduction to the wild felids'). Additional principal sources were the IUCN Red List of Threatened Species [IUCN, 2011] (http://www.iucnredlist.org/) and The Encyclopaedia of Mammals [Macdonald, 2009]. Wild felids were classified according to the IUCN/SSC risk categories ('critically endangered', 'endangered', 'vulnerable', 'near threatened', 'least concern').

The situation for Primates was different because no single action plan covers this order (which numbers 411 species according to the IUCN classification [IUCN, 2011]). Therefore, we used the IUCN Red List of Threatened Species as a principal source for information on the threats faced by, and status of, all primates [IUCN, 2011]. We supplemented this information using Mammals of Africa (MOA) [Butynski et al., in press] and the only published IUCN/SSC Action Plan for primates, that for African primates [Oates, 1996; Butynski et al., in press]. Further information was obtained from the list of 25 primate species identified by Mittermeier et al. [2009] as the most endangered primates in 2008-2010. Inclusion on Mittermeier's list was on the basis of very small population sizes and a very rapid decrease in numbers [Mittermeier et al., 2009]. In total, we had a sample of 357 primates for which we knew something of their distribution and IUCN threat status.

For each species of felid and primate, we noted the threats identified by the authors as severest. These are reviewed below for each taxon according to main categories, and broadly sequenced within each category by geographical region. In addition, the threat data are summarised in online supplementary tables 1 and 2 (for all online suppl. material, see www. karger.com/doi/10.1159/000342399). We then extracted and reviewed all mentions of proposed solutions and conservation actions that have already been put in place to combat the threats identified in the primary literature.

Species distribution maps were downloaded as ESRI shapefiles from the 2010.4 update of the IUCN Red List of Threatened Species [IUCN, 2011]. These geographic distribution maps are either true species range maps or maps based on the extent of occurrence. Extent of occurrence maps are defined by the IUCN as the area contained within the shortest continuous boundary encompassing all known, inferred or projected sites of occurrence. Where necessary, distribution of a given species consists of multiple polygons separated by areas of unsuitable habitat [IUCN, 2011]. Although species range maps are more accurate and to be desired for all species, lack of knowledge prevents mapping to this level of detail for some species at present. Spatial analyses were conducted using R-version-2.13.1 [2011]. Species shapefiles were converted from polygons of species distributions into raster cells to produce species presence/absence layers in a grid of $1^{\circ} \times 1^{\circ}(111.12 \times 111.12 \mathrm{~km})$ squares. Overlaying the presence/absence grid layers of all felids and all primates enabled analysis of species co-occurrence in various regions across the globe through cross-tabulation. Attribute data for all species were assigned to each grid cell, which enabled selective mapping and analysis of species of both taxa facing various threats.

\section{Results}

Of the 357 primate species in our sample, 224 were threatened ( 23 near threatened, 78 vulnerable, 86 endangered and 37 critically endangered), and of the 36 species of wild felids 25 were threatened ( 9 near threatened, 9 vulnerable, 6 endangered and 1 critically endangered). Figure 1 maps the geographical distributions of these threatened species, for felids (fig. 1a) and primates (fig. 1b), showing the numbers present in each grid cell (in all appropriate figures, map locations are indicated by 


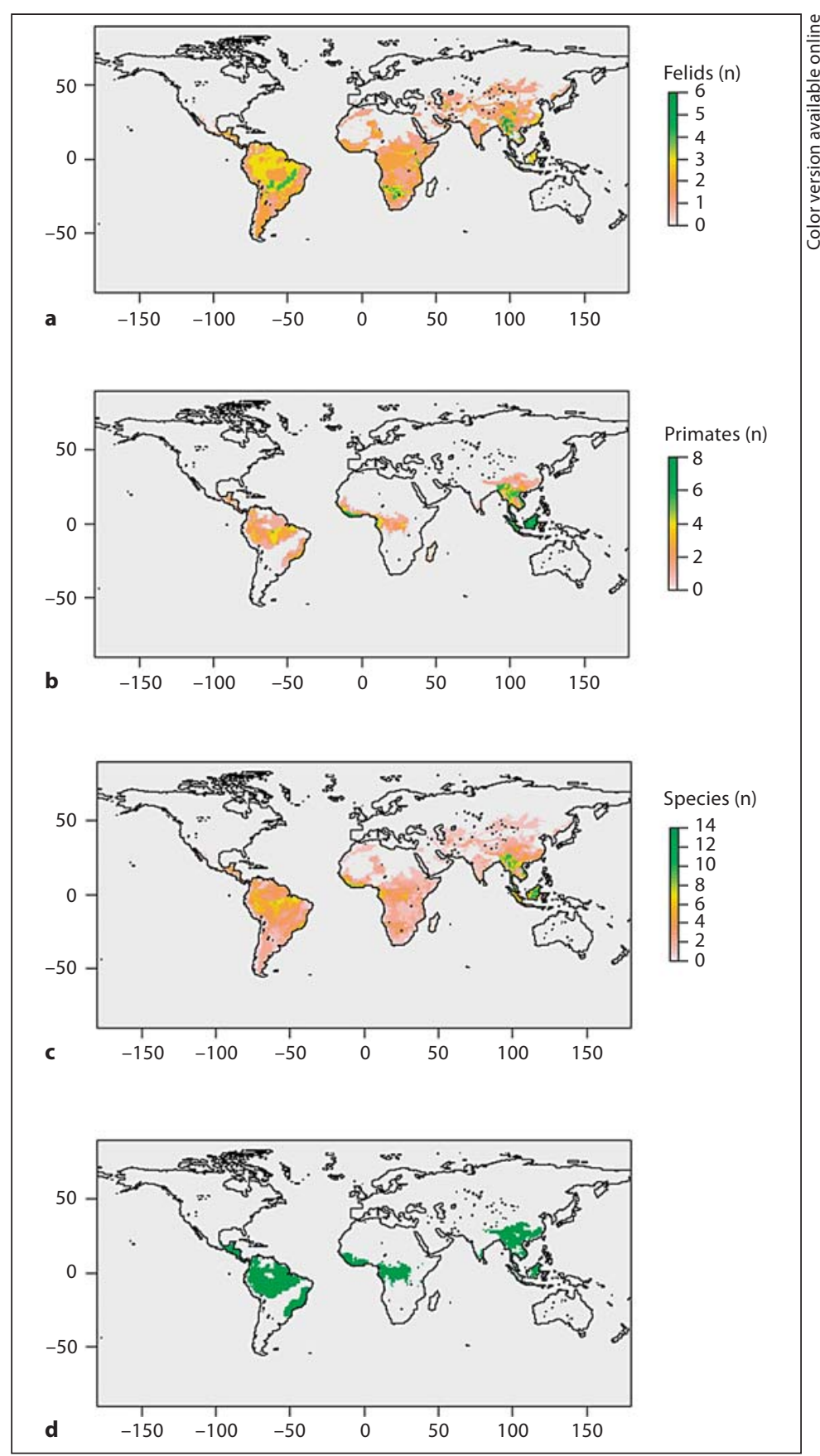

Fig. 1. Geographic distributions of threatened felids (a), primates (b) and species from both taxa (c) revealing the number of threatened species of each taxon in $1^{\circ} \times 1^{\circ}$ grid cells. $\mathbf{d}$ Distribution of grid cells where at least 1 species from both taxa is threatened (shaded areas). Outlined in black are coastlines and major inland water bodies.

174 Folia Primatol 2012;83:171-215 Macdonald/Burnham/Hinks/Wrangham 
Fig. 2. a CI biodiversity hotspots (shaded in grey) and locations where at least 1 threatened primate and at least 1 threatened felid occur (shaded in black). b Those areas of the felid-primate hotspots which are not contained in the CI biodiversity hotspots.

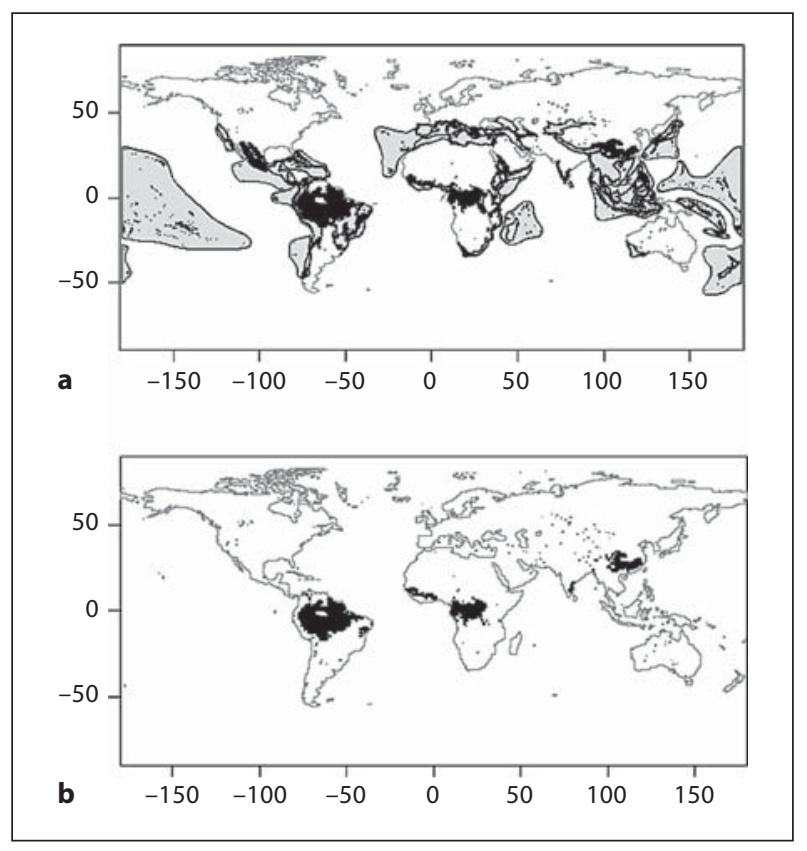

decimal degrees). A maximum of 6 threatened felid species was found to co-occur in a grid cell, and 8 threatened primates. Figure 1c combines these data to depict the grid cells falling within the geographical ranges of at least 1 threatened species of either taxon. The aggregate scores ranged from 1 (1 threatened species of either taxon) to 14, with the most speciose grid cells being in Central and South Asia. The modal value is a single threatened species. Of the total area occupied by at least 1 threatened felid or primate species, $24.7 \%$ contained 2 threatened species from our panels, $12.8 \%$ contained 3 species, and $37.7 \%$ contained 4 or more. $35.9 \%$ of the total land area occupied by threatened felids contained 2 species of this taxon, $15.9 \%$ contained 3 felid species and $4.3 \%$ contained 4 or more species. For threatened primates, $22.7 \%$ of the land area they occupy contained 2 threatened species of primate, $12.6 \%$ contained 3 and $23.2 \%$ contained 4 or more. Figure $1 \mathrm{~d}$ shows those areas where at least 1 species of both taxa are threatened. Of the land area covered by the distribution of at least 1 threatened species of felid or primate, $83.3 \%$ contain at least 1 species of both taxa. This offers coarse-grained support for the hypothesis that threatened members of these taxa co-occur.

CI biodiversity hotspots are considered highly threatened biogeographic regions that hold particularly large numbers of species found nowhere else. These hotspots are defined as containing $50 \%$ of all threatened mammals as endemics. There are 34 biodiversity hotspots (fig. $2 \mathrm{a}$ ), and some overlap with regions identified here as containing at least 1 threatened felid and 1 threatened primate species ('felid-primate hotspots'). $39.4 \%$ of the area that contains threatened felids and primates is also covered by biodiversity hotspots. For threatened felids alone, this figure is $26.9 \%$. For threatened primates alone, this figure is $44.8 \%$. Two points emerge. First, biodiver- 


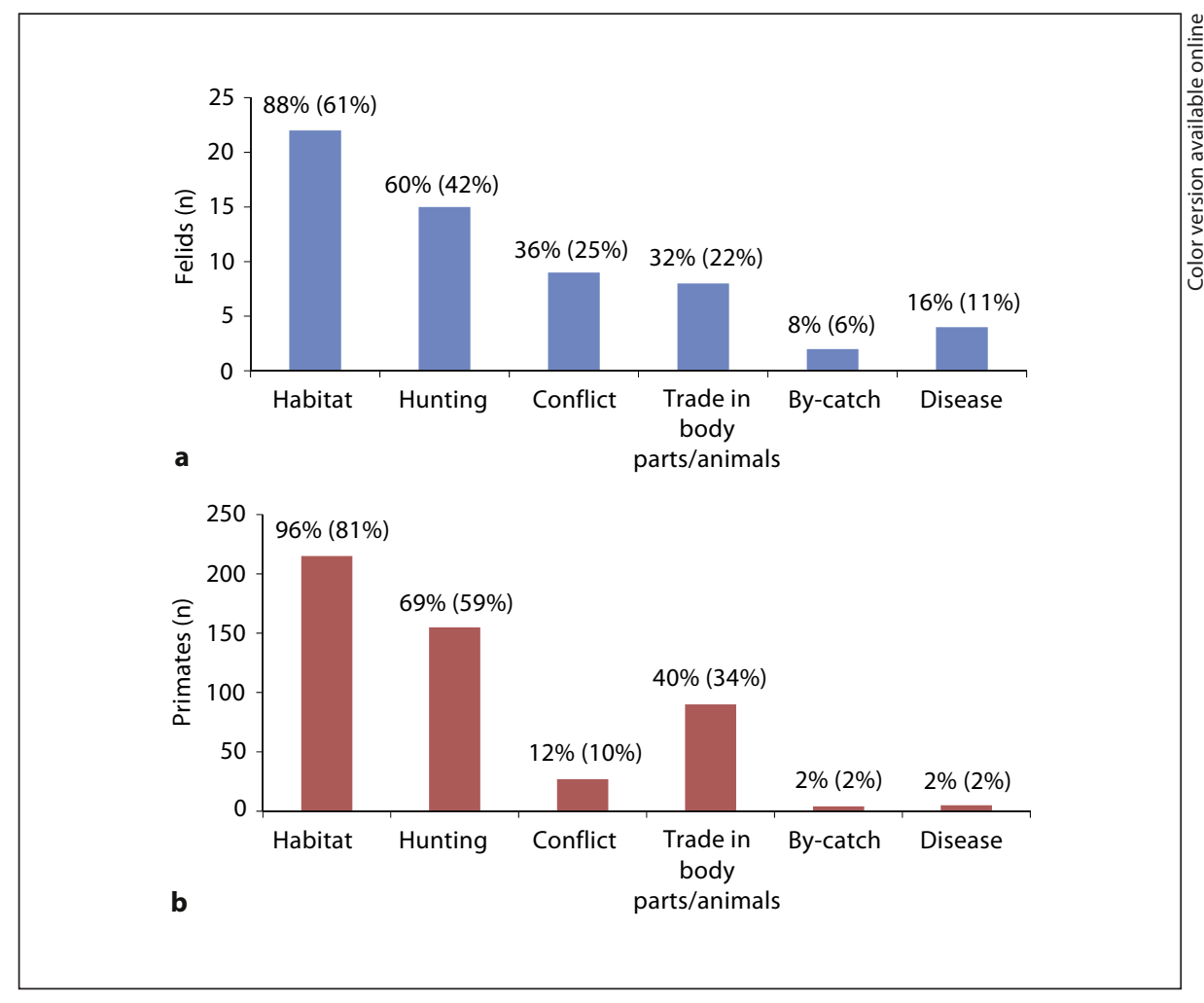

Fig. 3. The number of species of felids (a) and primates (b) from our panels of threatened species for which a given threat is listed as a cause for their threatened status. Data labels show the percentage of our panel of threatened felids (a) and primates (b) that face a given threat (values in parentheses show the percentage of species of the whole taxon, regardless of whether currently classified as threatened or not, facing a given threat). Thus, habitat loss was listed as a principal threat to 22 species of threatened felids, which amounts to $88 \%$ of threatened felids, and $61 \%$ of all felids.

sity hotspots cover approximately $40 \%$ of the grid cells where at least 1 threatened primate and at least 1 threatened felid occur and hence primates and felids could be used as charismatic umbrella species to help protect these hotspots. Second, the majority of grid cells (approx. 60\%) containing at least 1 each of threatened felids and primates are not encompassed in biodiversity hotspots (fig. $2 \mathrm{~b}$ ), reminding us that important priorities exist beyond these hotspots.

The major, broad categories of threat facing felids and primates are habitat loss (degradation and fragmentation), hunting, conflict, trade, by-catch and disease (other, less frequently reported categories, such as genetic problems, are covered in the review below). Figure 3 displays the distribution of these threats in terms of the numbers of threatened species for which each was recorded for felids (fig. 3a) and primates (fig. 3b). Felids and primates frequently encounter the same threats, and in 
approximately the same ratios, including habitat loss, hunting and capture for trade in body parts or live animals, with the first two of these threats being the most serious for many species of both taxa. Whilst conflict with humans is relatively uncommon for primates, more than a third of all felids are in conflict, often as a result of persecution due to their perceived risk to humans and livestock. By-catch is rarely reported as a direct threat to either primates or felids. Small numbers of felid and primate species were recorded as facing the threat of infectious diseases, either directly from humans, or from contact with domesticated animals. All but 1 case of disease-threatened primates ( 5 species) and half of all disease-threatened felids (3 species) are found in Africa. This includes the African wildcat, a subspecies of Felis silvestris of which two other subspecies are also threatened by infectious disease transmission in Eurasia. African primates threatened with disease include gorillas (Gorilla gorilla), chimpanzees (Pan troglodytes) and bonobos (Pan paniscus), which are at severe risk of Ebola fever and other diseases readily transmitted from contact with humans. Geoffroy's cat (Leopardus geoffroyi) is the only disease-threatened felid in the Neotropics and the Yucatan black howler monkey Alouatta pigra, which is susceptible to yellow fever epidemics, is the only disease-threatened primate in the Neotropics [Marsh et al., 2008].

To explore the congruence between places where particular threats are listed for both felids and primates, we compared the distribution of threatened species associated with specific threats. Considering 4 main categories of threats (habitat loss, hunting, conflict, and trade in body parts or as captive live animals), the maps show grid cells falling within the geographical distributions of threatened felids (fig. $4 \mathrm{a}, \mathrm{c}$, e, g) and of threatened primates (fig. $4 \mathrm{~b}, \mathrm{~d}, \mathrm{f}, \mathrm{h}$ ), for which each of these 4 threats was identified as a cause for concern in our primary review literature.

Figure $5 \mathrm{a}-\mathrm{d}$ combines the priority threats for both taxa to depict the distribution of grid cells for which at least 1 species of each taxon is thought to be threatened by habitat loss (fig. 5a), hunting (fig. 5b), conflict (fig. 5c) or trade (fig. 5d). If we consider the global distribution of threats, the importance of trade for primates differs markedly: it is high in Asia (nearly as important as hunting) and the Neotropics (where it is also a frequent threat) compared to Africa (where it is much less often cited as a concern). The distribution of primates and felids threatened by habitat loss and hunting is very similar, but different from that of conflict and trade. Many species threatened by habitat loss are also threatened by hunting, although there are a few cases where only one or the other threat is important. For example, in India, felids and primates are threatened by habitat loss, but not hunting. Conflict with humans is generally recorded for cases of crop raiding as pest species (primates) or as a perceived risk to livestock and humans (felids), so this threat tends to be prevalent in other areas than those facing habitat loss, hunting and poaching for trade (more typically focussed around forests).

To further examine the hypothesis that species of both taxa face the same threats in the same places, table 1 summarises the numbers of $1^{\circ} \times 1^{\circ}$ grid cells which occur within the geographical distributions of at least 1 species of threatened felid or primate, with respect to habitat loss, hunting, conflict and trade. It displays the numbers of cells in which at least 1 threatened representative of both taxa occurs (cells supporting the hypothesis), as opposed to those in which only species of one or the other taxon occurs (contrary to the hypothesis), with respect to 4 broad categories of threat. Taking these major threats, plus the additional threats of disease and deple- 


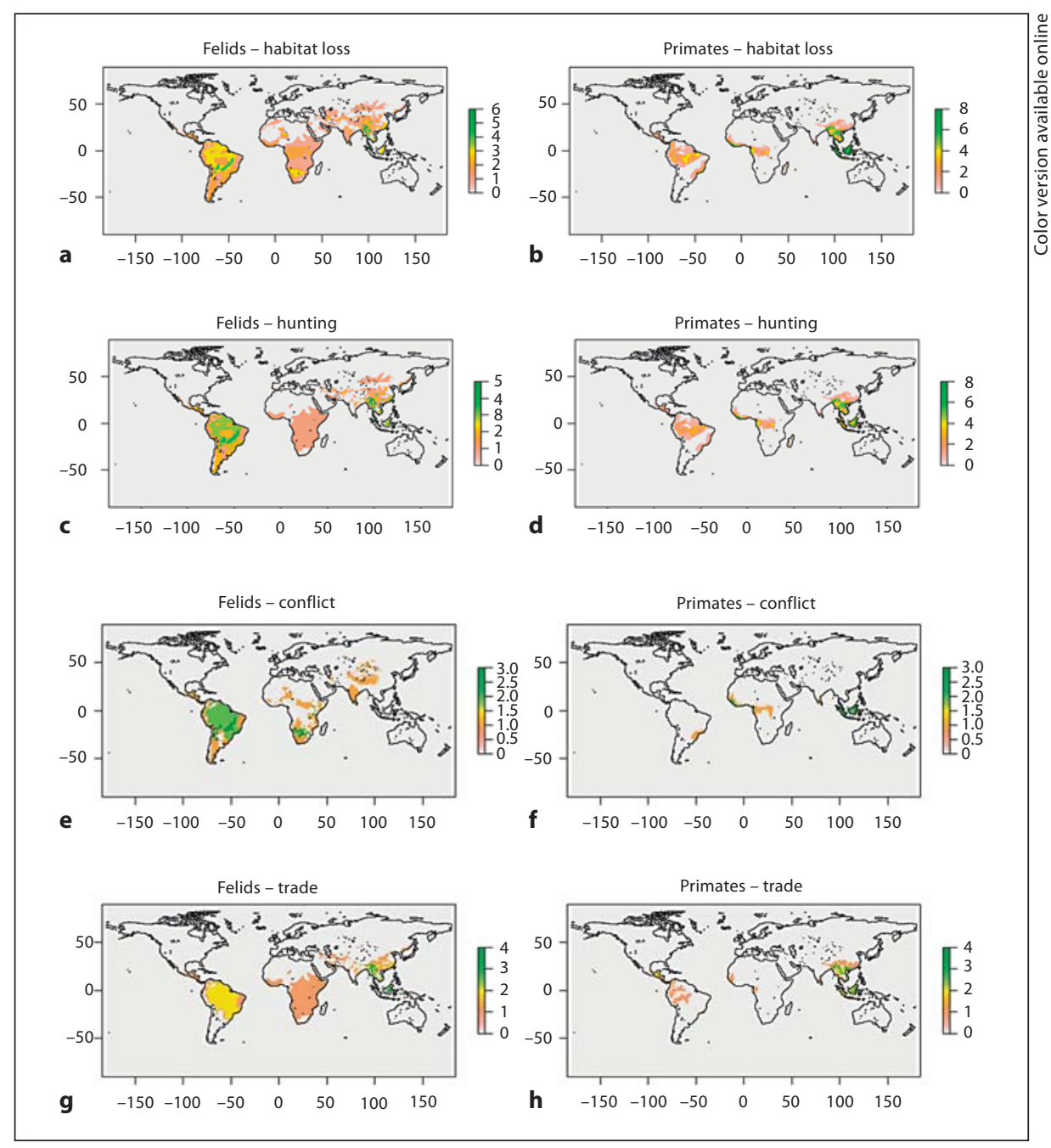

Fig. 4. Distribution of threatened felids and threatened primates displayed for each of 4 broad categories of threat identified as priority risks to those species in our primary review literature: habitat loss, hunting, conflict with humans and trade in live animals and body parts (an individual species may be at risk from more than one threat). Outlined in black are coastlines and major inland water bodies.

tion through by-catch, table 2 examines the regional variation in the number of species of both taxa for which each threat is recognised as important. It shows that habitat loss and hunting are a cause of between one third and half of all felids and primates being classed as threatened. Trade is a cause of greater concern for both taxa in Asia than it is in either Africa or the Neotropics, whereas conflict is more frequently cited as a threat in Africa and the Neotropics, especially for felids. Disease and by-catch seem to be threats more common to the threatened species of Africa, 

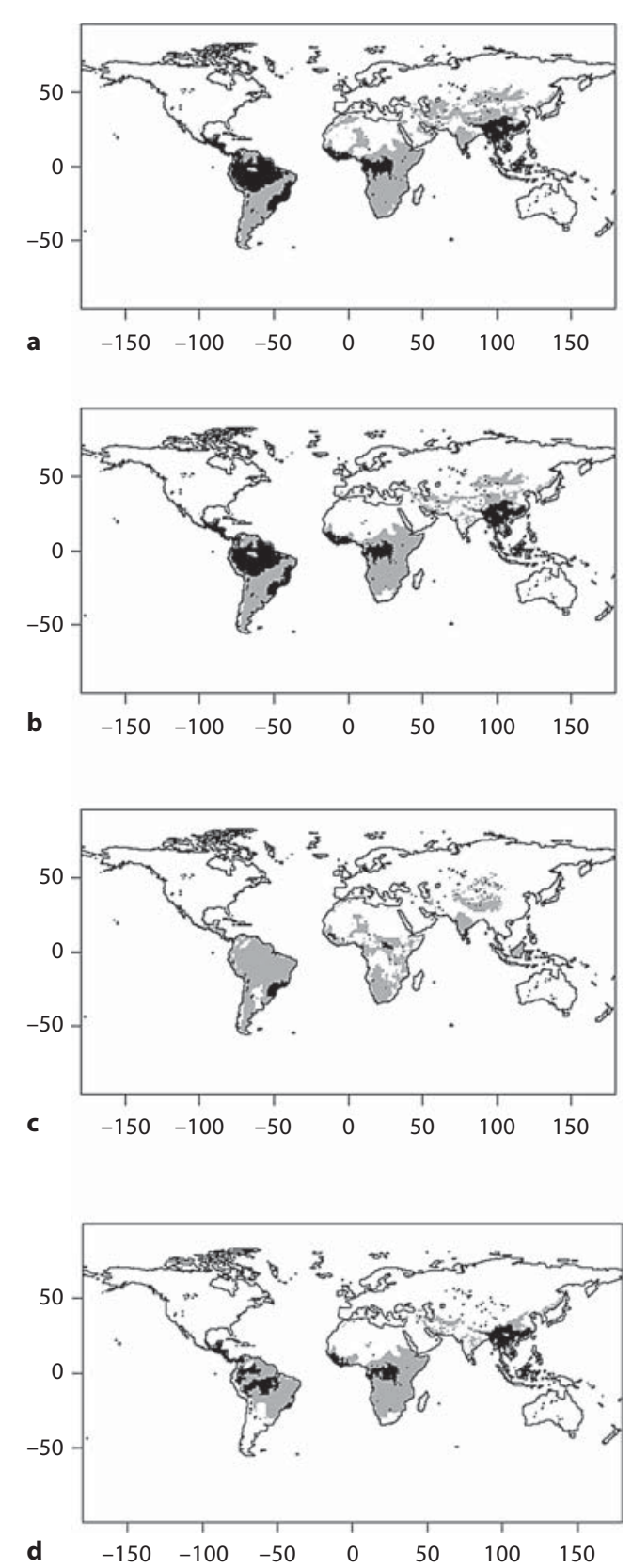

Fig. 5. Distribution of grid cells which contain 1 or more threatened felid species and 1 or more primate species afflicted by habitat loss (a), hunting (b), conflict (c) and trade (d). Grey shading indicates the presence of either threatened primates or felids, black shading indicates where at least 1 threatened species of each taxon coexists. Outlined in black are coastlines and major inland water bodies. 
Table 1. The number of $1^{\circ} \times 1^{\circ}$ grid cells for each threat in which 1 or more threatened felids, 1 or more threatened primates, at least 1 of each taxon, 1 or more felids but no primates, and 1 or more primates but no felids are subject to that threat

\begin{tabular}{|c|c|c|c|c|c|}
\hline Threat & $\begin{array}{l}1 \text { or more } \\
\text { felids }\end{array}$ & $\begin{array}{l}1 \text { or more } \\
\text { primates }\end{array}$ & $\begin{array}{l}\text { At least } 1 \text { felid and } \\
1 \text { primate }\end{array}$ & $\begin{array}{l}1 \text { or more } \\
\text { felids and } \\
\text { no primates }\end{array}$ & $\begin{array}{l}1 \text { or more } \\
\text { primates and } \\
\text { no felids }\end{array}$ \\
\hline \multicolumn{6}{|l|}{ All regions } \\
\hline Habitat & 4,988 & 1,021 & $734(14.7 ; 71.9)$ & 4,254 & 287 \\
\hline Hunting & 4,242 & 1,000 & $657(15.5 ; 65.7)$ & 3,585 & 343 \\
\hline Conflict & 2,601 & 400 & $59(2.3 ; 14.8)$ & 2,542 & 341 \\
\hline Trade & 3,390 & 1,083 & $608(17.9 ; 56.1)$ & 2,782 & 475 \\
\hline One or more threats & 4,999 & 2,147 & $1,448(29.0 ; 67.4)$ & 3,551 & 699 \\
\hline \multicolumn{6}{|l|}{ Africa } \\
\hline Habitat & 2,330 & 338 & $295(12.7 ; 87.3)$ & 2,035 & 43 \\
\hline Hunting & 1,912 & 330 & $270(14.1 ; 81.8)$ & 1,642 & 60 \\
\hline Conflict & 692 & 251 & $38(5.5 ; 15.1)$ & 654 & 213 \\
\hline Trade & 1,912 & 267 & $219(11.5 ; 82.0)$ & 1,693 & 48 \\
\hline One or more threats & 2,341 & 338 & $297(12.7 ; 87.9)$ & 2,044 & 41 \\
\hline \multicolumn{6}{|l|}{ Asia } \\
\hline Habitat & 1,054 & 582 & $338(32.1 ; 58.1)$ & 716 & 244 \\
\hline Hunting & 743 & 572 & $289(38.9 ; 50.5)$ & 454 & 283 \\
\hline Conflict & 460 & 147 & $19(4.1 ; 12.9)$ & 441 & 128 \\
\hline Trade & 351 & 408 & $0(0.0 ; 0.0)$ & 351 & 408 \\
\hline One or more threats & 1,054 & 990 & $338(32.1 ; 34.1)$ & 716 & 652 \\
\hline \multicolumn{6}{|l|}{ Neotropics } \\
\hline Habitat & 1,604 & 101 & $101(6.3 ; 100.0)$ & 1,503 & 0 \\
\hline Hunting & 1,587 & 98 & $98(6.2 ; 100.0)$ & 1,489 & 0 \\
\hline Conflict & 1,449 & 2 & $2(0.1 ; 100.0)$ & 1,447 & 0 \\
\hline Trade & 1,127 & 408 & $389(34.5 ; 95.3)$ & 738 & 19 \\
\hline One or more threats & 1,604 & 819 & $813(50.7 ; 99.3)$ & 791 & 6 \\
\hline
\end{tabular}

Values in parentheses represent the percentages of the grid cells containing threatened felids and primates, respectively, that would be protected if areas where both threatened felids and threatened primates exist were protected for each threat. For example, in the Neotropics, if the 813 grid cells occupied by at least 1 threatened species of both felid and primate were protected, this would deliver protection to $99.3 \%$ of the cells containing threatened primates and $50.7 \%$ of the cells containing threatened felids. Data are given for all regions, plus separately for each of 4 broad categories of threat identified as priority risks to those species in our primary review literature.

although these two threats are not frequently cited as a cause for concern in any region. For each threat, we used contingency tables to compare the proportions of threatened felids and primates in Africa, Asia and the Neotropics. The proportions of threatened felids and primates in each of the three regions were not significantly different for any of the threats except conflict (Fisher's exact test, d.f. $=2, p=0.007$; 
Table 2. Regional variation in threats

\begin{tabular}{|c|c|c|c|}
\hline & Felids & Primates & Total \\
\hline \multicolumn{4}{|l|}{ Habitat } \\
\hline Africa & $6(33.3)$ & $36(40.9)$ & $42(39.6)$ \\
\hline Asia & $11(40.7)$ & $80(36.9)$ & $91(85.8)$ \\
\hline Neotropics & $9(34.6)$ & $61(51.3)$ & $70(66.0)$ \\
\hline \multicolumn{4}{|l|}{ Hunting } \\
\hline Africa & $2(11.1)$ & $31(35.2)$ & $33(31.1)$ \\
\hline Asia & $8(29.6)$ & $60(27.6)$ & $68(64.2)$ \\
\hline Neotropics & $7(26.9)$ & $35(29.4)$ & $42(39.6)$ \\
\hline \multicolumn{4}{|l|}{ Conflict } \\
\hline Africa & $4(22.2)$ & $10(11.4)$ & $14(13.2)$ \\
\hline Asia & $2(7.4)$ & $15(6.9)$ & $17(16.0)$ \\
\hline Neotropics & $6(23.1)$ & $2(1.7)$ & $8(7.5)$ \\
\hline \multicolumn{4}{|l|}{ Trade } \\
\hline Africa & $2(11.1)$ & $6(6.8)$ & $8(7.5)$ \\
\hline Asia & $6(22.2)$ & $59(27.2)$ & $65(61.3)$ \\
\hline Neotropics & $3(11.5)$ & $20(16.8)$ & $23(21.7)$ \\
\hline \multicolumn{4}{|l|}{ By-catch } \\
\hline Africa & $1(5.6)$ & $1(1.1)$ & $2(1.9)$ \\
\hline Asia & $(0.0)$ & $3(1.4)$ & $3(2.8)$ \\
\hline Neotropics & $(0.0)$ & $(0.0)$ & 0 \\
\hline \multicolumn{4}{|l|}{ Disease } \\
\hline Africa & $3(16.7)$ & $4(4.5)$ & $7(6.6)$ \\
\hline Asia & $(0.0)$ & $(0.0)$ & 0 \\
\hline Neotropics & $1(3.8)$ & $1(0.8)$ & $2(1.9)$ \\
\hline
\end{tabular}

The number of species of threatened primates and felids in each region for which threat categories are listed as causes of their threatened status. Figures in parentheses give the percentages of threatened species of that taxon in that region. The final column gives the total number of primates and felids facing a given threat in that region. For example, there are 6 felid species threatened by habitat loss in Africa, which represents 33.3\% of all threatened felids in Africa, and in total there are 42 felids and primates threatened by habitat loss in Africa.

online suppl. table 3). There is a significant relationship between taxon and region for conflict; the proportions of felids and of primates facing this threat vary between the three regions. Conflict with humans differs between primates and felids, insofar as felids are mostly persecuted for being a threat to domestic stock (or to humans), whereas primates come into conflict with humans as a result of crop raiding. Thus, regional variation in the predominant agricultural practice and also cultural beliefs associated with pest species will mean conflict with humans is a threat that is more prevalent in some regions than others for both felids and primates.

The hypothesis that felids and primates face broadly similar threats in the same places can be tested at a smaller spatial scale. A closer look at the distribution of threatened species in Africa, for example, reveals that in some ecoregions, one or other taxon is at greater risk of a particular threat (table 3; fig. 6, 7). There are 16 
Table 3. The number of primate and felid species facing the threats of habitat loss, hunting and conflict with humans in each of the ecoregions of Africa (as described by WWF)

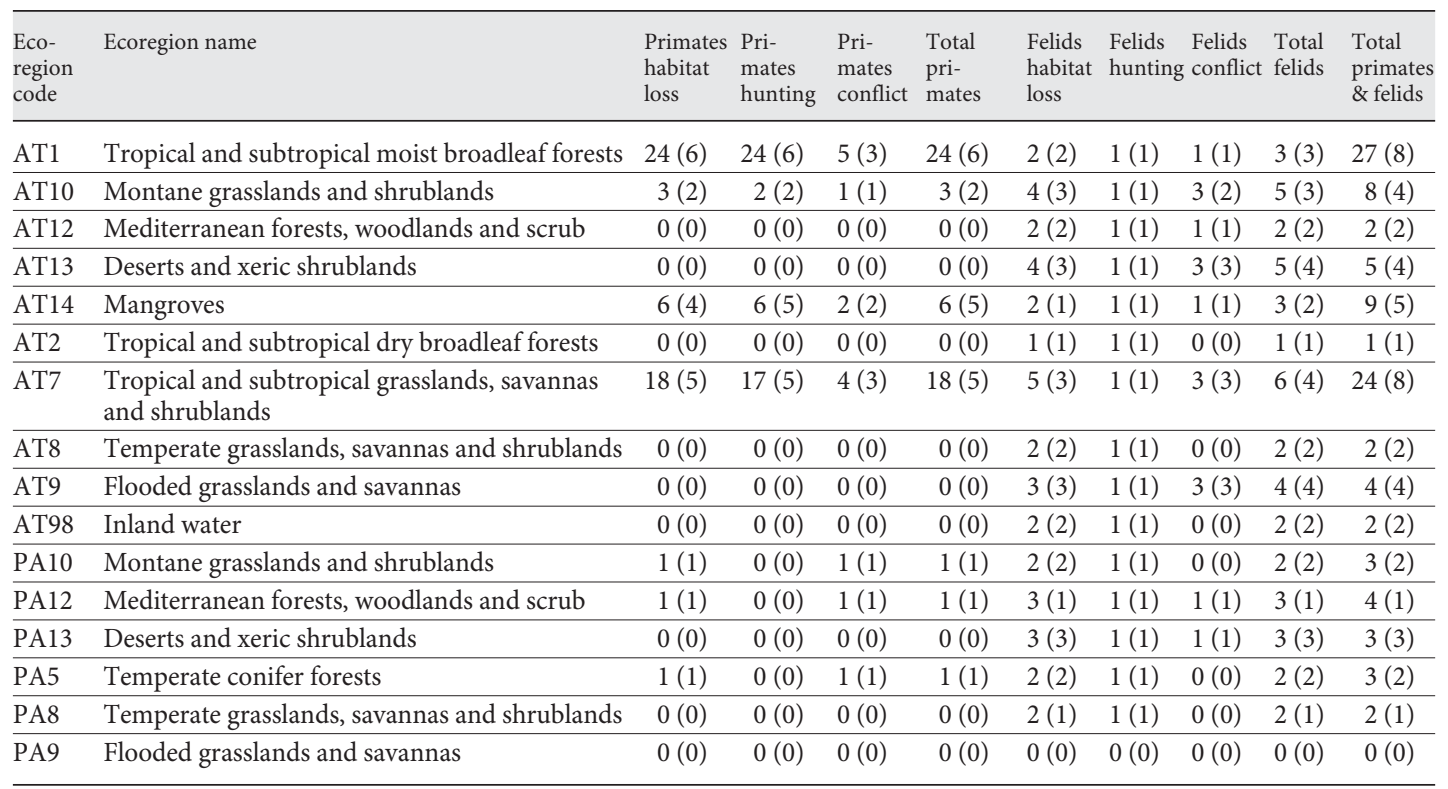

Numbers in parentheses are the maximum number of species co-occurring in any single $1^{\circ} \times 1^{\circ}$ grid cell.

Ecoregion codes: $\mathrm{AT}=$ Afrotropics, $\mathrm{PA}=$ Palearctic.

ecoregions distributed in 238 patches in Africa. The data for Africa consider all threatened species of each taxon, and this is the only region for which a complete action plan exists (now updated in MOA [Butynski et al., in press]). Therefore, for this continent we address in more detail the hypothesis that representatives of both taxa face the same threats in the same places. Ecoregion AT1 (tropical and subtropical moist broadleaf forests) and ecoregion AT7 (tropical and subtropical grasslands, savannahs and shrublands) are, for our two taxa, the most speciose ecoregions in Africa, with a total of 27 and 24 species (felids and primates aggregated), respectively. Inevitably, the species distributions are not perfectly congruent with the ecoregion boundaries so, for example, the 3 felid species threatened by conflict each occur in only a fraction of AT7 (where 4 species of primate are also threatened by conflict). A series of contingency tables analysed using Fisher's exact test (for small expected frequencies) revealed no significant difference in the numbers of felids and primates facing the threats of habitat loss, hunting or conflict with humans in either of these ecoregions, nor for any other African ecoregions, again in accordance with the hypothesis of shared problems in the same places.

Across Africa, of the 4 felids in conflict with people, 3 were threatened, whereas of the 16 primates in conflict, 9 were threatened, a difference which is not statistically significant (Pearson's $\chi^{2}$ test with Yates' continuity correction $\chi^{2}=0.013$, d.f. $=$ $1, \mathrm{p}=0.9092)$. 


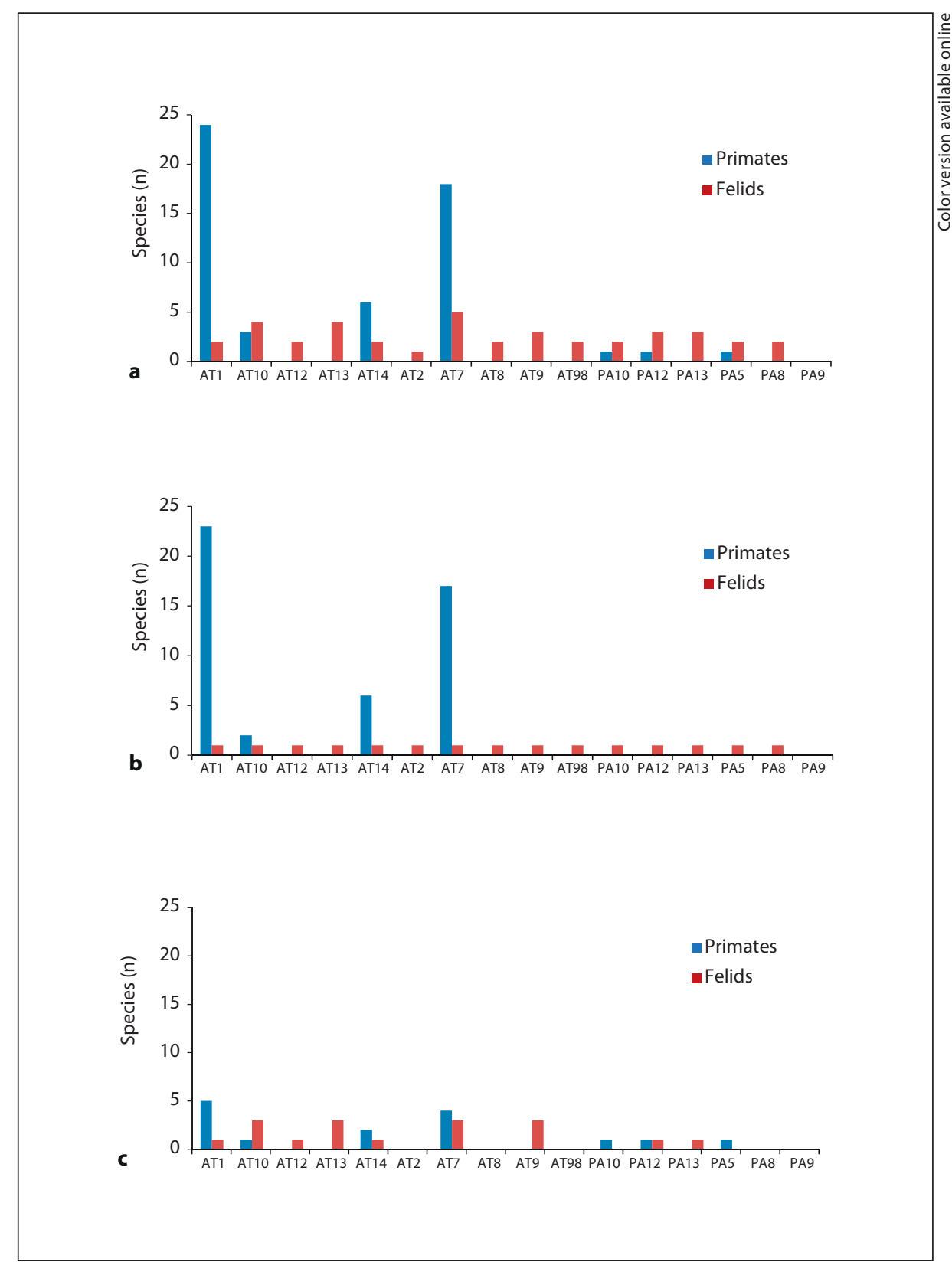

Fig. 6. The number of species of primates and felids facing the threat of habitat loss (a), hunting (b) and conflict with humans (c) in each of the ecoregions found in Africa (see table 3 for ecoregion descriptions). 


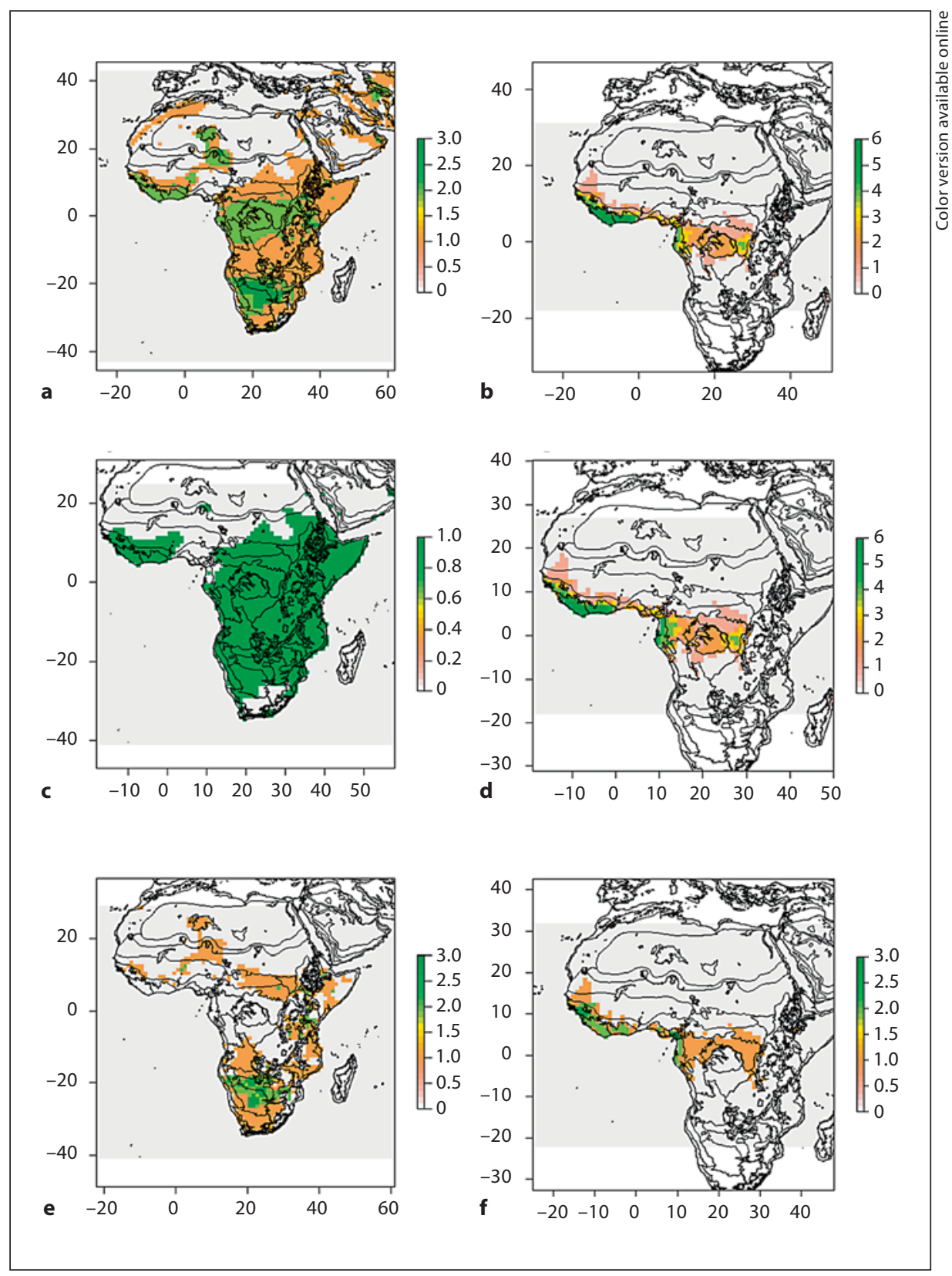

Fig. 7. Felids (a, c, e) and primates (b, d, f) in Africa facing the threats of habitat loss (a, b), hunting $(\mathbf{c}, \mathbf{d})$ and conflict with humans $(\mathbf{e}, \mathbf{f})$. Shading shows the maximum number of species cooccurring at the resolution of $1^{\circ} \times 1^{\circ}$ grid cells. Ecoregions found in Africa are outlined in black (see table 3 for ecoregion descriptions). 


\section{Threats}

\section{Habitat Loss, Degradation and Fragmentation}

Time and again the same syndrome recurs in the predicaments described for our panel of primates. That is, species that were formerly widespread and at least moderately abundant now face all the hazards characteristic of small, isolated populations due to the impacts of rampant habitat loss, degradation and fragmentation, combined with hunting, generally for meat. As industries such as logging and mineral extraction open up access to forests and there is greater demand for meat from immigrating workers [Zommers and Macdonald, 2012], so hunting tends to increase. In our review, it is often impossible to disentangle the effects of habitat loss and overexploitation, or to apportion risk separately between components of this syndrome. Several of even the smallest felids are threatened by habitat loss. The 1.8$2.5 \mathrm{~kg}$ black-footed cat Felis nigripes and the $2-3.2 \mathrm{~kg}$ sand cat F. margarita [Macdonald and Loveridge, 2010] are threatened by overgrazing and agriculture which deplete their small mammal prey [IUCN, 2011], while the rodents on which servals (Leptailurus serval) depend are reduced by annual burning and overgrazing of grassland. The moist forests inhabited by African golden cats (Caracal aurata) are being degraded and replaced by savannahs, and cheetahs (Acinonyx jubatus), too, are threatened by habitat degradation, especially in semi-arid areas of West Africa.

\section{African Species}

MOA [Butynski et al., in press] identifies 39 species of primate (approx. 45\% of the total listed) which were assessed by the IUCN in 2010 as having a status of 'near threatened' or above. In all cases the top threat listed was either habitat loss/degradation (29 cases) or hunting ( 25 cases), and these threats co-occurred in 21 cases. The other threats listed were disease ( 2 cases), killed as an agricultural pest (3 cases) and removal for the pet trade (itself a variant on the hunting syndrome; 3 cases). Of the 9 felid species found in Africa, 6 are near threatened or at greater risk. All but 1 of these species is threatened by habitat loss (lions, Panthera leo, are the exception), but only 1 is considered at risk due to hunting (leopard, Panthera pardus). Amongst African primates, a prime example of the habitat/hunting syndrome is the critically endangered Niger Delta red colobus monkey Procolobus epieni, which was locally common when first discovered two decades ago, but logging and habitat degradation as a result of oil extraction activities, and greater hunting for commercial bushmeat encouraged by the development of the oil industry in the region, have all put pressure on this species. Close variants of this syndrome characterise Pennant's red colobus (Procolobus pennantii) [Hearn et al., 2006], Preuss' red colobus (Procolobus rufomitratus) [Oates et al., 2008d], the Zanzibar red colobus (Procolobus badius kirkii) [Struhsaker and Siex, 2008] and the endangered Uhehe red colobus (Procolobus gordonorum; half of the Magombera Forest has been destroyed in the last three decades, so only around 450 monkeys survive in the remaining $6 \mathrm{~km}^{2}$ of the forest with scant evidence of movement between patches [Oates, 1996; Struhsaker et al., 2008]). An even more punishing variant of the habitat loss/fragmentation and hunting syndrome is illustrated by two further critically endangered African colobines, Miss Waldron's red colobus monkey (Procolobus badius waldroni) [McGraw, 2005; Oates et al., 2008c] (now possibly extinct [Oates, 2011]) and the Tana River red colobus 
(Procolobus rufomitratus; 50\% of its habitat have been lost to agriculture in the last two decades [Mittermeier et al., 2009]), neither of which is currently located in any protected area, a blight also common to Sclater's guenon (Cercopithecus sclateri) and Diana monkey (Cercopithecus diana) in the Ivory Coast [Oates et al., 2008b].

Sclater's guenon (vulnerable) is just one in a long list of African species for which the exacerbating interaction between habitat loss and hunting is devastating. Others include the endangered Preuss' guenon Cercopithecus preussi (little of its native montane forest remains in the mainland part of its range) and the critically endangered kipunji Rungwecebus kipunji, only discovered in 2003 and confined by logging, charcoal production, farming and illegal hunting to increasingly isolated and shrinking fragments of the Rungwe-Kitulo forests [Davenport and Jones, 2008]. The suntailed guenon Cercopithecus solatus is threatened by hunting in the vicinity of logging camps [Oates, 1996] and a similar scenario afflicts the endangered Barbary macaques (Macaca sylvanus) whose habitat is disappearing due to logging, charcoal production, land clearance and habitat degradation from overgrazing [Butynski et al., 2008]. Habitat loss is a severe threat to the drill Mandrillus leucophaeus (endangered) and mandrill M. sphinx (vulnerable); the drill has been totally displaced in the centre of its range (between Douala and Edea in Cameroon) as a result of chipboard manufacturing and human settlements [Oates and Butynski, 2008a]. Slash-andburn agriculture has reduced chimpanzee habitat across West and Central Africa by $80 \%$ [Kormos et al., 2003]. The main threats to bonobos (also endangered) are commercial logging, agriculture, traditional slash-and-burn agriculture and expanding human settlements. The Cross River gorilla Gorilla gorilla diehli is critically endangered and threatened by habitat loss due to agricultural development, fires to clear forest or improve pasture and roads that fragment their habitat [Oates et al., 2007].

\section{Asian Species}

In the Asian cat guilds, clouded leopards (Neofelis nebulosa) and marbled cats (Pardofelis marmorata) occupy the world's fastest declining forests (over 10\% in the last decade, FAO 2007 in Sanderson et al. [2008a]). Endangered Bornean bay cats (Pardofelis badia) are threatened by commercial logging and oil palm plantations, with Bornean forest cover predicted to fall from $50 \%$ to less than one third by 2020 [Rautner, 2005]. The risk to flat-headed cats (Prionailurus planiceps) on Borneo is exacerbated by water pollution through agricultural run-off contaminating their prey [Collins et al., 1991; Rautner, 2005; Wilting et al., 2010]. Rice paddy and other irrigation-based methods of cultivation render wetland unsuitable for fishing cats (Prionailurus viverrinus) [Nowell and Jackson, 1996], which are further threatened by pollution, hunting and overfishing. In contrast, leopard cats ( $P$. bengalensis) are tolerant of deforestation, although the island subspecies, the Iriomote cat (P. b. iriomotensis) and the Visayan leopard cat (P. b. rabori), of the Philippine islands of Panay, Negros and $\mathrm{Cebu}$, are, respectively, critically endangered and vulnerable [Sanderson et al., 2008a]. Habitat loss and fragmentation impact larger species particularly and thus represent a major threat to tigers (Panthera tigris).

Forest loss (often the same forest whose loss threatens felid species) is also a risk to primates. For example, the Sarawak surili Presbytis chrysomelas, once common, is now critically endangered and amongst the rarest primates in the world. It is found in only 5\% of its historic range [Nijman et al., 2008] as a result of habitat loss to oil palm plantations. The primary threat to the Sumatran orang-utan Pongo abelii is 
habitat loss and fragmentation, and even small-scale selective logging can reduce local orang-utan densities by as much as 60\% [Mittermeier et al., 2009]. Roads further fragment suitable habitat and increase access for logging and hunting operations [Mittermeier et al., 2009]. Similarly threatened are the white-headed black langur Trachypithecus poliocephalus leucocephalus in China, the black-crested gibbon Nomascus concolor (habitat loss accelerating a decline initiated by hunting) [Bleisch et al., 2008b], the northern white-cheeked gibbon in China and Vietnam N. leucogenys [Geissmann et al., 2000] and the Cao-vit crested gibbon N. nasutus, which is blighted by cultivation, livestock grazing, charcoal production and firewood collection [Geissmann and Bleisch, 2008]. Another primate threatened by the dangerous cocktail of habitat loss and a concurrent increase in hunting pressure is the western hoolock gibbon Hoolock hoolock, for which agricultural encroachment, tea plantations and slash-and-burn cultivation have been exacerbated by capture for trade and hunting for food and medicine [Brockelman et al., 2008; Mittermeier et al., 2009]. This is further compounded by the hindrance to conservation efforts by political conflict in Myanmar along the borders with India and Bangladesh [Brockelman et al., 2008]. In the Vietnamese Central Highland forests, the grey-shanked douc langur Pygathrix cinerea loses almost 10,000 ha of its forest habitat annually as a result of logging, firewood collection and agricultural encroachment [Ngoc Thanh et al., 2008], while the critically endangered Tonkin snub-nosed monkey Rhinopithecus avunculus suffers massive deforestation, plus the effects of dam construction and intensive hunting pressures [Boonratana and Xuan Canh, 1998].

\section{Neotropical Species}

In the Neotropics, habitat loss was the most commonly cited threat to both felids and primates. One example of the impact of habitat loss on felids is how expansion of pine plantations, to the detriment of dry scrubland, has led to a $30 \%$ reduction in the guiña's (Leopardus guigna) Chilean range over two decades [Acosta and Lucherini, 2008]. Different causes of habitat loss, mining and fuel extraction, threaten Andean cats (L. jacobita) [Acosta et al., 2008]. Habitat loss is the main threat to ocelots (L. pardalis) and oncillas (L. tigrinus), their habitat is predicted to decline by $30 \%$ over the next two decades in the Brazilian Cerrado, for example [de Oliveira et al., 2008b], while conversion of these savannahs to agriculture also threatens the jaguarundi (Puma yagouaroundi). Jaguars (Panthera onca), classed as near threatened, are vulnerable to habitat loss and population fragmentation, as well as poaching of prey species and hunting; those in the Atlantic forests of Brazil, northern Argentina, central Honduras, and the Osa peninsula of Costa Rica are the most threatened [Sanderson et al., 2002].

Primate examples of the devastation of habitat loss in the Neotropics abound. The critically endangered cotton top tamarin Saguinus oedipus suffers forest loss to large-scale cattle ranching, farming, logging and oil palm plantations [Mittermeier et al., 2009], and the three protected areas within its range in Colombia have lost between 42 and $71 \%$ of their forests [Mittermeier et al., 2009]. Those forest fragments that remain are threatened by hydro-electric projects [Savage and Causado, 2008; Mittermeier et al., 2009]. Similarly, the blonde capuchin Cebus flavius falls to sugar cane plantations [de Oliveira et al., 2008a], the Ka'apor capuchin C. kaapori (which is found in just one protected area that has lost more than half of its forest) [Carvalho et al., 1999], the yellow-breasted capuchin C. xanthosternos (which is also heav- 


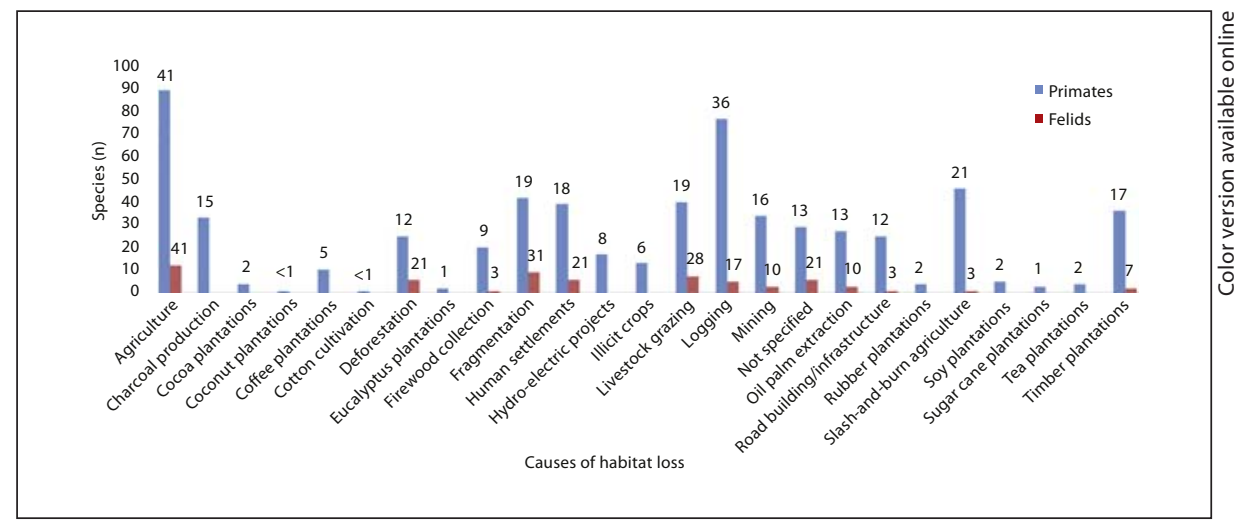

Fig. 8. The number of primates and felids threatened by the various causes of habitat loss. The percentage of the total number of threatened species of each taxon is given above each column.

ily hunted) [Kierulff et al., 2008], the blond titi monkey Callicebus barbarabrownae [Veiga et al., 2008a] and the San Martin titi monkey Callicebus oenanthe (which occupies areas that have lost $40 \%$ of their forest cover over 20 years [Veiga et al., 2011]) are facing habitat loss, fragmentation and hunting. The same trio of blights afflict the critically endangered black-bearded saki Chiropotes satanas which is already locally extinct in much of its original range, and similarly the northern muriqui Brachyteles hypoxanthus.

Summary and Commonality of Habitat Loss Threats to Primates and Felids

Habitat loss is a serious issue for almost all threatened felids and primates worldwide. The stated causes of habitat loss show similarities but also subtle differences between the threatened species of the two taxa (fig. 8). Agriculture (of an unspecified nature) is the most prevalent cause of habitat loss for both felids and primates, quoted for more than $40 \%$ of threatened species of both taxa. However, there are regional differences (fig. 9). Habitat loss is more widely attributed to agriculture for felids than primates in South America, and whilst primates do face this threat in sub-Saharan Africa, felids are reported to be at risk from agriculture in southern Africa more frequently than are primates. The other stated major causes of habitat loss for felids are fragmentation of suitable habitat (an issue for $31 \%$ of all threatened felids), livestock grazing (28\%), unspecified deforestation (21\%) and human settlements (21\%). Again, the regions where these causes of habitat loss are specified differ between felids and primates (fig. 9). Fragmentation of habitats is cited much more widely for felids in Asia, Africa and South America, although there are overlaps where species from both taxa are affected by fragmentation. For primates, in addition to general agricultural encroachment, a wider range of causes of habitat loss is given (fig. 8), the most frequently cited of which are logging (36\% of all threatened primates; fig. 8), slash-and-burn agriculture (21\%), habitat fragmentation (19\%), livestock grazing (19\%) and human settlements (18\%) (fig. 8). The building of roads and similar infrastructure, such as railway lines, is cited as a cause of habitat loss threat- 


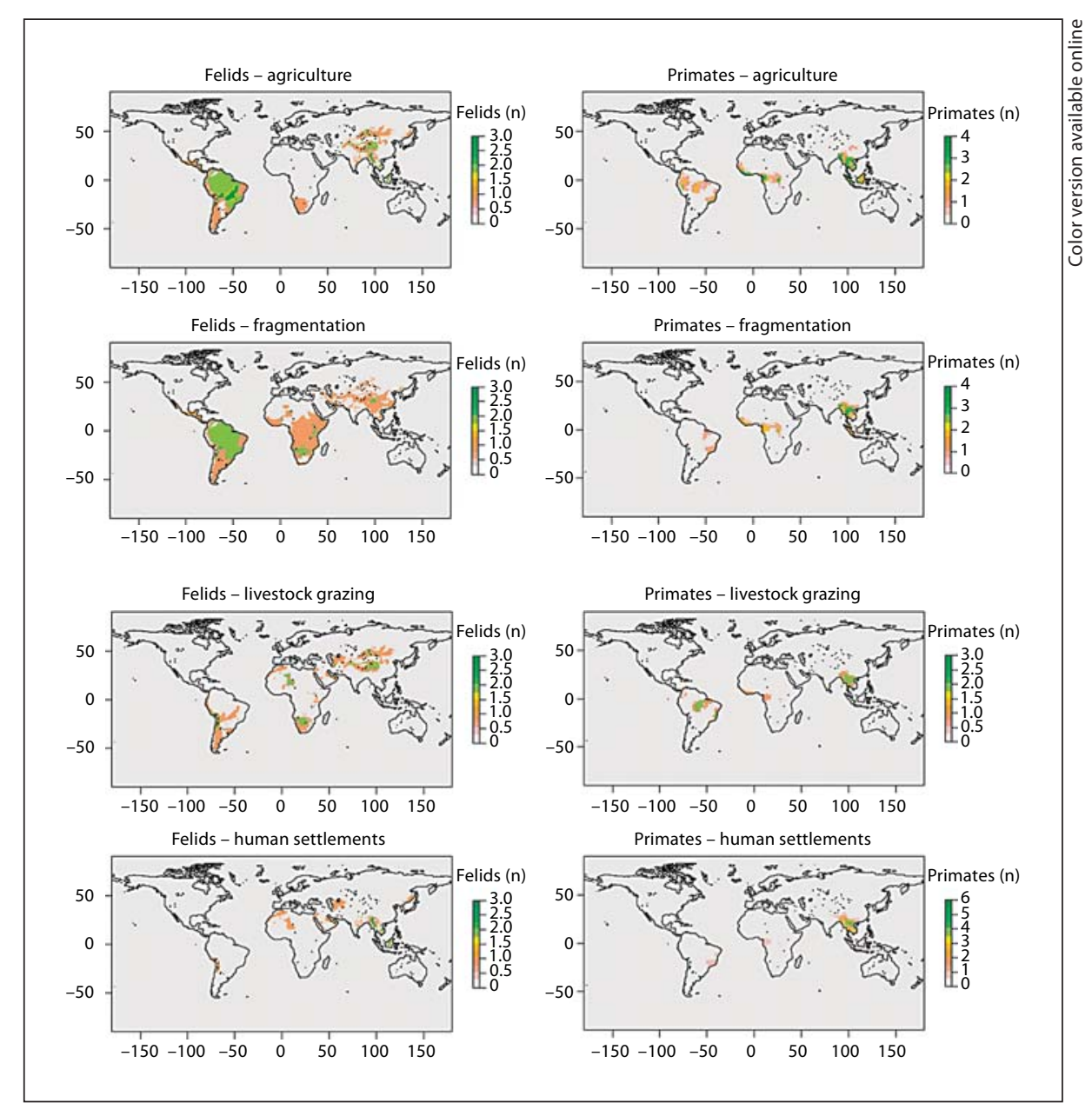

Fig. 9. Distribution of felids and primates threatened by the most common causes of habitat loss (agricultural encroachment, habitat fragmentation, livestock grazing and the spread of human settlements). Outlined in black are coastlines and major inland water bodies.

ening primates in $12 \%$ of cases, which is 4 times more frequent than for felids, suggesting road networks pose less of a boundary issue for the wider-ranging felids than for primates. Charcoal production and hydro-electric projects are responsible for habitat loss threatening 15 and $8 \%$ of primates, respectively, but are not cited as a significant threat to felids.

In short, the loss, degradation and fragmentation of habitat is high on the list of threats to almost every felid, from the loss of deciduous forests for rusty-spotted cats (Prionailurus rubiginosus) [Nowell and Jackson, 1996], reclamation and destruction of wetlands for jungle cats (Felis chaus) to deforestation of suitable moist evergreen and dry deciduous forests for Asiatic golden cats (Pardofelis temminckii). Habitat 
Fig. 10. Distribution of primates threatened by habitat loss as a result of logging, a threat that is common to primates but much less so for felids. Outlined in black are coastlines and major inland water bodies.

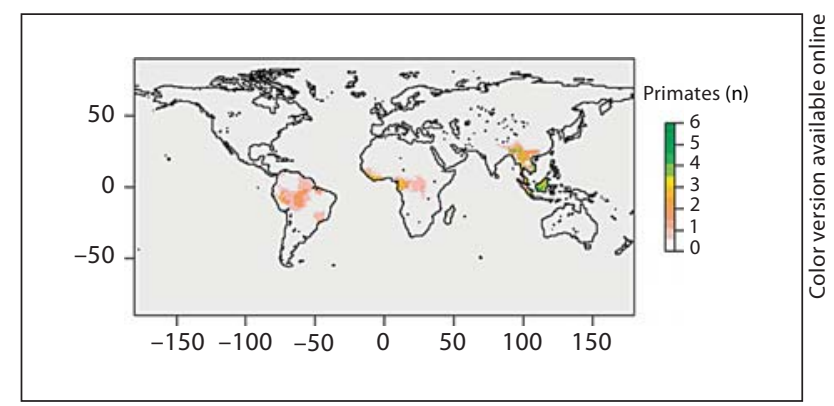

degradation threatens the manul Otocolobus manul [Ross et al., 2008], while deforestation is a principal threat to Canadian lynx Lynx canadensis and Asiatic wildcats Felis silvestris ornata and conversion of pasture-scrub-woodland to wheat fields and forest plantations exacerbated the plight of the Iberian lynx Lynx pardinus, as does the loss of dry scrub and oak and pine forests for bobcats L. rufus in Mexico. It is similarly pervasive as a threat to primates, but the accounts of primates much more frequently link habitat loss to unsustainable hunting levels. So while our review demonstrates that habitat loss directly affects both primates and felids, the effects of the associated hunting pressure may differ.

\section{Hunting}

\section{Direct Effects on Primates}

Habitat loss is frequently accompanied by an increase in hunting for meat to feed the workers upon which the processes resulting in habitat loss depend. In Africa, bushmeat hunting is a serious threat to many primates and is pervasive in the south-east area of the Ivory Coast [Oates et al., 2008c] where it has probably resulted in the extinction of Miss Waldron's red colobus [McGraw, 2005; Oates, 2011]. Hunting similarly afflicts Pennant's red colobus, of which fewer than 10,000 may survive and more than 550 were estimated to have been killed in 2004 [Hearn et al., 2006]. Preuss' red colobus are hunted unsustainably [Oates, 1996; Oates et al., 2008d], as is the Uhehe red colobus [Oates, 1996; Struhsaker et al., 2008], the West African red colobus, especially Procolobus badius badius in the eastern part of its range [Mittermeier et al., 2009], the sun-tailed guenon [Oates and Bearder, 2008], and the vulnerable Diana monkey which has been driven extinct in Ghana by hunting [Oates et al., 2008b]. Drills are particularly susceptible because entire harems may be shot, which increases the species' vulnerability, especially in Nigeria and on Bioko Island [Oates and Butynski, 2008a]. The same is also true for mandrills (classed as vulnerable), whose meat is highly prized in Gabon [Oates and Butynski, 2008b]. As roads open up hitherto impenetrable forest, chimpanzees are hunted for bushmeat, the pet trade and medicinal purposes. While traditionally there were cultural bars on hunting bonobos, they too are increasingly hunted [Oates, 1996; Hohmann and Fruth, 2008]. In Madagascar, hunting is cited as a major component of the syndrome threatening the silky sifaka Propithecus candidus [Andrainarivo et al., 2008a], Sclater's black le- 
mur Eulemur flavifrons (also prized by the pet trade) [Andrainarivo et al., 2011], the critically endangered Sahafary sportive lemur Lepilemur septentrionalis [Andrainarivo et al., 2008b], and the aye-aye Daubentonia madagascariensis [Andrainarivo et al., 2008c]. There is also increasing use of lemurs for meat [Barrett and Ratsimbazafy, 2009; Barrett et al., in press].

In Asia, the motive for hunting is not just for bushmeat, but for traditional medicine, this being cited as especially important for Delacour's langur Trachypithecus delacouri [Nadler et al., 2008], the white-headed langur [Bleisch et al., 2008c] and the northern white-cheeked gibbon [Geissmann et al., 2000; Bleisch et al., 2008a]. All these gibbons are hunted for food, traditional medicines and the pet trade, as is the Cao-vit crested gibbon [Bleisch and Geissmann, 2008] and the western hoolock gibbon, for which hunting is common in Bangladesh, India and Myanmar [Brockelman et al., 2008]. Grey-shanked douc langurs are also hunted for bushmeat, traditional medicine and for the pet trade [Long, 2004; Ngoc Thanh et al., 2008], and the same suite of threats afflicts the Tonkin snub-nosed monkey [Boonratana and Xuan Canh, 1998] and the Siau Island tarsier Tarsius tumpara, which has a tiny distribution amidst degraded habitats on a single volcanic island [Mittermeier et al., 2009; Shekelle and Salim, 2010]. The critically endangered Celebes crested macaque Macaca nigra has been unsustainably hunted for bushmeat and for the pet trade [Supriatna and Andayani, 2008], as has the Pagai Island macaque M. pagensis [Whittaker, 2006; Whittaker and Mittermeier, 2008]. The Javan slow loris Nycticebus javanicus is victim of a massive demand for the traditional medicine and pet trades [Nekaris and Shekelle, 2008; Mittermeier et al., 2009].

In the Neotropics, 20,000-40,000 cotton top tamarins were exported to the USA for use in biomedical research in the 1960s and 1970s. Although this has now ceased, it has depleted populations even in areas of suitable habitat. A major threat to the blonde capuchin is hunting for food and the pet trade [de Oliveira et al., 2008a], as it is for the San Martin titi monkey [Veiga et al., 2011], while the yellow-breasted capuchin faces both high rates of habitat loss and is heavily hunted [Kierulff et al., 2008]. The critically endangered northern muriqui Brachyteles hypoxanthus, hunted for food and sport, survives in isolated populations, none of which alone is viable [Mendes et al., 2008]. This is also the case for the Colombian woolly monkey Lagothrix lugens in the face of coca plantations [Stevenson and Link, 2008]. Both subspecies of the critically endangered variegated spider monkey Ateles hybridus face the syndrome of habitat loss, hunting and the pet trade, and this species is certainly a favourite game species in the Perijá Mountains [Urbani et al., 2008].

\section{Direct Effects on Felids}

The larger species of felid are greatly preferred by trophy hunters, whereas felids of all sizes are impacted by other forms of trade. Similarly, primates of all sizes may be hunted for their body parts, or as pets. Trade in fur and body parts was cited as an important risk factor for Asian golden cats, fishing cats in India [Sunquist and Sunquist, 2002], both species of clouded leopard, marbled cats, and Bornean bay cats, which is said to have increased in value because of its subsequent rarity [Sunquist and Sunquist, 2002; Kitchener et al., 2004; Mohd-Azlan and Sanderson, 2007]. Similarly, in South America, Andean cat body parts and pelts have totemic significance [Villalba et al., 2004, 2012]. Pampas cats (Leopardus colocolo) and oncillas are hunted for the same purpose. Historically high hunting pressure has had a long-reaching 
impact on the conservation status of numerous species, even when the hunting pressure has been drastically reduced in more recent times. Hunting for Geoffroy's cat between the 1960s and 1980s is thought to have depleted their populations, and hunting also depleted the formerly numerous ocelot population in Venezuela [Nowell and Jackson, 1996]. Further north, bobcats were the most heavily harvested cat species in the last three decades of the 20th century, and are still legally harvested for the fur trade in 38 US states and 7 Canadian provinces [Kelly et al., 2008]. The bobcat is now the leading felid in the skin trade, with most exports coming from the USA, and it is not clear whether this is sustainable [Kelly et al., 2008]. Commercial trapping for $\operatorname{lynx}(\operatorname{Lyn} x \operatorname{lyn} x)$ fur in Eurasia may be a threat, but its impact is unknown [Breitenmoser et al., 2008]. Although exports of pelts were high in Russia and China up until the early 1990s, subsequently export quotas have reduced the numbers to less than 1,000 annually [Nowell and Jackson, 1996]. Manuls were historically hunted extensively for their fur, and today they are hunted on permit in Mongolia for 'household purposes', although the suspicion is that many manul furs are illegally exported to China [Murdoch et al., 2006]. Formerly, Asiatic wildcats were hunted in large numbers for their pelts, and pelt-hunting threatened leopard cats in China. Trade in manuls, Asiatic cats and leopard cats has, at least, been much more strictly controlled since the mid-1990s [Nowell and Jackson, 1996].

For larger felids, illegal trade for bones and pelts is a serious threat. Examples of felids faced with hunting for body parts are snow leopards (Panthera uncia) and, notoriously, tigers [Chundawat et al., 2010]. Hunting of threatened felids is not always prohibited; hunting for puma (Puma concolor) is legal and regulated in Canada, Mexico, Peru and the USA, and jaguar trophy hunting is permitted in Bolivia. There are quotas for the legal hunting of leopards in Botswana (130 per annum), Central African Republic (40), Ethiopia (500), Kenya (80), Malawi (50), Mozambique (60), Namibia (250), South Africa (150), Tanzania (500), Zambia (300) and Zimbabwe (500) (RevCoP13). Leopard skins are in demand for ceremonial dress amongst Zulu royalty and dignitaries, and the Christian Baptist animist religion, Shemba, founded in 1906, extends this 'right' to all male adherents [T. Dickerson, pers. commun.]. Where leopards are protected, there are generally exemptions for killing problem animals. Leopard abundance in Africa is poorly researched, as carnivores are notoriously difficult to count, yet these data are essential in determining a sustainable level of trophy off-take [Balme et al., 2010]. Leopards have recently been upgraded from 'least concern' to 'near threatened' on the IUCN Red List. The global population trend is decreasing, and the combined effects of ever increasing habitat loss and human persecution are so significant that these cats may soon qualify for 'vulnerable'. Moreover, the presence of hunters with guns in previously inaccessible habitats may leave felid species more vulnerable to opportunistic hunting for saleable pelts, as well as falling victim to by-catch.

Sport hunting generally operates within some form of market wherein price indicates desirability, and Prescott et al. [2012] raise the alert that deteriorating IUCN status may prompt higher prices. Johnson et al. [2010] revealed this size effect for trophy felids. Big trophy means high price tag, to the extent that 500-1,000 lions are shot for trophies annually in Africa at about USD 50,000-100,000 per head, in an economy where both hard currency and lions are scarce [Loveridge et al., 2007]. As a result of the scarcity but high value of lions as hunting trophies, the viability of Hwange National Park's lion population in Zimbabwe was affected by the quota li- 
censed to the adjoining hunting estates. Since lion society is founded on male coalitions, shooting a male lion disrupts his coalition, prompting faster turnover, increased infanticide and other multiplier effects cascading from one death. Loveridge et al. [2007] report that the quota of males for shooting in 2000 was 60, in an area where only about 22 existed, and where $72 \%$ of the adult males they tagged were shot ( $82 \%$ of those shot were within $1 \mathrm{~km}$ of the park, and hunting accounted for $44 \%$ of the deaths of all adult males annually). The $15,000-\mathrm{km}^{2}$ Hwange National Park was too small because a vacuum at the boundary drew males from the interior of the park into the firing line of neighbouring hunting estates [Macdonald et al., 2010a].

Indirect Effects and Commonality of Threats between Primates and Felids

Obviously, direct hunting of both primates and felids, whether for trade, sport or bushmeat, carries the risk of unsustainability and negatively impacts their populations, especially where these activities take place without regulation, as is often the case. Less obviously, bushmeat hunting for subsistence protein, which so frequently accompanies deforestation, also has a negative effect on felids by depleting their prey resources. For example, the impact of bushmeat hunting on their antelope prey is likely to have serious consequences for African and Asian golden cats [Nowell and Jackson, 1996; Sanderson et al., 2008b] and leopards [Henschel et al., 2011]. Beyond protected areas, the wild ungulate prey of lions and tigers are generally depleted, not least by competition with domestic stock [Karanth and Stith, 1999]. Depletion of large ungulates in the high Central Asian mountains threatens snow leopards, as does the poisoning of pika and marmot populations (a practice officially banned in the late 1970s) in attempts to control bubonic plague and reduce competition with livestock. This action also imperils the manul [Smith et al., 1990]. Loss of their ungulate prey base is a threat to the Eurasian lynx especially during harsh winters [Pulliainen, 1992]. Logging and fire suppression activities can threaten Canada lynx, considered endangered in New Brunswick and threatened in the USA, by reducing the hares which are their staple diet. A major risk factor for the critically endangered Iberian lynx (which is believed to exist in only two populations of 24-33 adults in the Coto Doñana and $60-110$ in the eastern Sierra Morena) is the devastation of rabbit numbers by the myxomatosis poxvirus in the 1950s and viral haemorrhagic pneumonia in the late 1980s [von Arx and Breitenmoser-Wursten, 2008]. Grazing by domestic goats, sheep and camelids is thought to reduce the rodent prey of Andean cats [Villalba et al., 2004].

Predation (by feral dogs) was listed as a serious threat only for Barbary macaques [Butynski et al., 2008]. Nonetheless, decreasing primate populations may have a negative impact on the felids that predate them. Although not cited as a direct extinction threat, felids do regularly prey on primates [Burnham et al., 2012a, this vol.]. Hart [2007] estimated that felids account for more than 65\% (254/389) of the predator attacks on primates in Asia, and concludes that leopards and tigers have a large impact on Asian primates. In the Periyar Tiger Reserve, South India, more than $80 \%$ of leopard diet over a 3-year period was Nilgiri langur (Trachypithecus johnii) [Srivastava et al., 1996]. In Meru-Betiri Nature Reserve, Indonesia, langurs and macaques constituted more than $50 \%$ of the diet of leopards [Seidensticker and Syuono, 1980], and langurs also constitute between 5.7 and 7\% of tiger diet in India and Nepal. In Bangladesh, rhesus macaques (Macaca spp.) and langurs are the third highest component in tiger diets [Reza et al., 2001; Sankar and Johnsingh, 2002]. Seidensticker's [1983] review showed that the intensity of predation by tigers and leopards on ma- 
caques and surilis (Presbytis spp.) in 5 South Asian study sites negatively correlated with the availability and abundance of alternative prey. For example, in the Royal Chitawan National Park in Nepal, which has a diverse prey base, they only occasionally killed rhesus macaques (Macaca mulatta) and Himalayan langurs (Presbytis entellus). In Kanha National Park, central India, tigers only occasionally kill Himalayan langurs but leopards do so far more frequently. On Sri Lanka, where leopards are freed from competition with tigers for ungulates, they only occasionally killed $\mathrm{Hi}$ malayan langurs and purple-faced leaf monkeys. In Meru-Betiri Reserve, eastern Java, where ungulates are scarce, both big cats killed primates [Seidensticker, 1983].

In the Neotropics, where $83 \%$ of predation on primates is by raptors and only $3 \%$ attributed to felids, 2 large felids (jaguar and puma) and 4 small felids (ocelot, jaguarundi, margay F. wiedii, and oncilla) nonetheless may kill primates [Hart, 2007]. Emmons [1987] looked at the diet of the jaguar, puma and ocelot in lowland tropical rain forest in south-eastern Peru (Estación Biologica de Cocha Cashu, Parque Nacional Manu, Dpto. Madre de Dios, Peru). Primate remains identified were of brown mantled tamarin (Saguinus fuscicollis; taken by ocelot), common squirrel monkey (Saimiri sciureus; taken by ocelot and an unidentified big cat) and black spider monkey (Ateles paniscus; taken by jaguar and an unidentified big cat).

In conclusion, bushmeat and pet trade hunting, while directly negatively affecting primates, may also indirectly negatively affect felids through the removal of their prey base, not only primates but other prey species also consumed by humans. The lack of alternative food resources may, in turn, make felids more likely to take primates and therefore increase this source of pressure on populations that are already threatened. Bushmeat hunting, therefore, may have negative consequences for both felids and primates.

\section{By-Catch}

Felids are afflicted by traps set for other species and are thus captured as bycatch. For example, black-footed cats are poisoned and trapped during indiscriminate pest control [Silwa et al., 2010], snares and traps set for rabbits may kill Iberian lynx, as those set for foxes may kill Scottish wildcats [Macdonald et al., 2010b]. The major threat to lion conservation is retaliatory killing for livestock losses, but many lions are also killed in snares set for bushmeat [Loveridge et al., 2010]. Canadian lynx are killed in snares set for other predators in mainland USA [Nowell, 2008]. MOA [Butynski et al., in press] lists a number of primates as being susceptible to snare injuries. One such example is that of two populations of chimpanzees where between $27 \%$ and one third of adults exhibited snare injuries ranging from missing finger segments to severely deformed or missing hands and feet; injuries risking fatal infection or incapacity [Wrangham and Goldberg, 1997; Wrangham, 2000; Reynolds, 2005]. Sanje (Cercocebus sanjei) and red-capped mangabeys (C. torquatus) are both sometimes captured in snares set for other prey [Butynski et al., in press]. Sun-tailed guenons and agile mangabeys (Cercocebus agilis) may also be captured in non-selective ground snares usually set for duikers such as Cephalophus spp. Their vulnerability to such traps is due to their semiterrestrial habits, and thus snares represent an acute threat [Butynski et al., in press]. 


\section{Conflict}

Cats of all sizes face conflict with livestock owners. Of small species, retributive killing following poultry losses is listed amongst the threats for Asian golden cats, marbled cats, oncillas, ocelots, Pampas cats and Geoffroy's cats [Lucherini et al., 2008]. Bobcats are persecuted as perceived predators of sheep in central Mexico [Sunquist and Sunquist, 2002] and caracals (Caracal caracal) are often persecuted for suspected predation on small livestock (mostly in South Africa and Namibia). As a parallel, several endangered primates are threatened by persecution in reprisals for crop raiding. This threat is cited for kipunjis, Barbary macaques [Butynski et al., 2008], drills [Oates and Butynski, 2008a], chimpanzees [Oates et al., 2008e], Pagai Island macaques [Whittaker, 2006], orang-utans [Ancrenaz et al., 2008; Singleton et al., 2008] and aye-ayes [Andrainarivo et al., 2008c].

Large felids eat larger prey [Carbone et al., 1999; Macdonald et al., 2012], and the considerable financial value of large domestic stock provokes serious conflict between people and all big cats [Macdonald et al., 2010a]. This poses a serious threat in particular to leopards, cheetahs, lions and jaguars [Caso et al., 2008]. Conflict with local communities over livestock depredation is also an important threat to snow leopards, especially where wild prey have been depleted and thus snow leopards are forced to find alternative food resources [Miller and Jackson, 1994; Schaller et al., 1994]. Persecution for livestock predation is listed as the main threat to pumas, in part because they typically return to their kills over several days and so can easily be poisoned by retributive farmers.

Primates, too, may come into conflict with humans, primarily due to crop raiding activities. For the Peruvian yellow-tailed woolly monkey Oreonax flavicauda, for example, the impact of subsistence hunters on their conservation status is worsened by persecution for crop raiding [Cornejo et al., 2008]. Similarly, a number of species of primates are listed in MOA [Butynski et al., in press] as being shot as crop pests, including the small-eared greater galago Otolemur garnettii, golden-bellied mangabey Cercocebus chrysogaster and olive baboon Papio anubis, which is officially classified as 'vermin' under the African Convention. The endangered Zanzibar red colobus, of which fewer than 2,000 individuals remain in a very restricted area in Zanzibar, is also persecuted as a crop pest. Approximately half of the remaining Zanzibar red colobus population is living outside protected areas. Although relatively few of these species are endangered per se (many are currently classed as 'least concern'), expanding human populations and persistent persecution may well lead to an upgrading of the conservation status of these species. A recent systematic study of crop raiding by primates on farms adjacent to the Budongo Forest Reserve, Uganda, found that a variety of deterrents were successfully employed by farmers to protect their crops [Hill and Wallace, 2012]. These included barriers, alarms, repellents and guarding crops (but not killing or trapping the animals). However, while all techniques resulted in reducing crop raiding of target fields, use of deterrents simply shifted raiding to nearby unprotected farms. Thus, to be effective, measures to resolve the conflict between humans and crop raiding primates or livestock hunting felids should also consider the impacts for neighbouring farms, such that all vulnerable locations are protected simultaneously. 


\section{Zoonotic Infection}

Both felids and primates face the threat of disease, either transmitted directly from humans or from domesticated animals. Because of their close relationship with domestic cats, wildcats are susceptible to diseases common in peridomestic cats, such as feline panleukopenia [Mendelssohn, 1989]. This has been highlighted as a threat to sand cats, Geoffroy's cats and wildcats [Nowell and Jackson, 1996; Macdonald et al., 2010b]. Similarly, the threat of infectious disease contracted from humans is cited for apes, such as chimpanzees at Gombe, Mahale and Taï National Parks, and raises a spectre from tourism and research. Ebola fever has killed chimpanzees in the Ivory Coast, and epidemics in remote protected areas in Gabon and the Republic of Congo have caused declines in gorilla and chimpanzee populations [Formenty et al., 1999; Huijbregts et al., 2003; Walsh et al., 2005; Walsh, in press]. Sylvatic yellow fever killed several hundred vulnerable black-and-gold howler monkeys (Alouatta caraya) in the southern Brazilian state of Rio Grande do Sul in 2008 [Bicca-Marques, 2009]. Disease is highlighted as an as yet unquantified risk for Cross River gorillas [Oates et al., 2007] and bonobos [Fruth et al., 2008].

The gorillas are phylogenetically close to humans and so highly susceptible to numerous human diseases. To quote Butynski et al. [in press]:

Of particular concern at this time is the fact that, each year, thousands of tourists from hundreds of different localities around the world step out of crowded, poorly ventilated airplanes and airports and within 1-2 days are close to, and sometimes touching, habituated G. beringei [Butynski and Kalina, 1998; Sandbrook and Semple, 2006]. The introduction of a human-borne infection into small, stressed, genetically depressed populations of Eastern gorillas could lead not only to the extinction of the population, but also (where the subspecies is represented by but one population) to the extinction of the subspecies [Butynski and Kalina, 1998].

A loose analogy might be drawn with the threat faced by felids of infections from domestic stock, as illustrated by the impact of distemper on Serengeti lions [Craft, 2010] (reviewed by Munson et al. [2010]).

\section{Solutions}

\section{How Effectively Can a Synergistic Approach Add Value to Single-Species Actions?}

In summary, our review reveals that species on our panels of both threatened felids and primates often face several threats and that the representatives of both taxa often face some, if not all, of the same broad categories of threat in the same place. In particular, habitat loss, trade (of bushmeat, pelts or live animals for the pet industry) and subsistence/bushmeat hunting are all principal threats for both taxa. Macdonald and Sillero-Zubiri [2004] point out that not only is there a limited number of threats to mammalian species in general (they were considering canids, but the principle applies widely), but there is also only a limited number of solutions to alleviate them. Perhaps inevitably our review revealed a platitudinous symmetry: where the threat is habitat loss, the solution lies in protecting habitat. The question is how to do this most effectively and efficiently. 


\section{Multifaceted Threats Shared within and between Taxa}

Our review of threats faced by felids and primates highlights the degree to which entwined syndromes, as opposed to individual threats, afflict many species. The action plans for both taxa reflect this in proposing multifaceted conservation action plans. For example, the Cat Action Plan [Nowell and Jackson, 1996] prioritises support of the Far East Leopard Fund to benefit Amur leopards through (i) antipoaching protection in the Kedrovaya Pad Nature Reserve, (ii) a captive breeding programme and (iii) lobbying for the creation of a new reserve. Another typical 'basket' of action is support for Project Snow Leopard and the International Snow Leopard Trust to deliver, in Central Asia, (i) involvement of local people, (ii) improved management of mountain reserves, (iii) local conservation initiatives, (iv) reduced poaching, (v) regional cooperation and (vi) identifying and establishing habitat corridors and transboundary reserves. In Europe, another example of this combination of conservation actions for felids is the Iberian Lynx Study Group, which supports a long-term study in Spain to deliver (i) population status surveys, (ii) genetic and pathological research, (iii) habitat use in the presence of other predators, (iv) habitat corridors, (v) modelling population viability, (vi) pilot reintroductions, (vii) monitoring the effects of habitat management and rabbit restocking and (viii) research into controlling competing predators. In the Americas, support of the National Center for Research, Management and Conservation of Predators in Brazil is intended to deliver, for jaguars, (i) resolution of human/carnivore conflicts, (ii) coordinated reintroduction and translocation projects, (iii) general research, (iv) education programmes and (v) compensation schemes.

Similarly, primate species tend to be afflicted by a basket of multifaceted problems, many of them the same as those affecting felids, and prompting similar solutions. For example, Oates et al. [2008e] formulate a highly integrated plan for chimpanzees, which already occur in multiple national parks, but which need (i) stricter enforcement of wildlife laws, (ii) better management of protected areas and (iii) range-wide surveys in the aftermath of Ebola virus, commercial hunting and the extractive industries. Regarding bushmeat, chimpanzee conservation is deemed to need (i) closer integration with mining, oil and logging industries (an approach yielding success in Central Africa), emphasising (ii) education on conservation status and (iii) economic alternatives to hunting and to agricultural practices that demand large tracts of land. A similarly integrated approach identifies key priorities for the Cross River gorilla: (i) control hunting and (ii) protect habitat and bring migration corridors into conservation management plans [Oates et al., 2008a].

As the proposed actions to protect individual species often include several diverse components, the priority solution is often to catalyse action by the establishment of coordinating and motivating specialist networks. One such example is the Global Cheetah Forum (affiliated with the IUCN Conservation Breeding Specialist Group) and the North African Regional Cheetah Action Group (NARCAG/OGRAN) [Durant et al., 2008]. Another example of coordination of groups that all aim to conserve an individual species is a planning conference in 2008 which brought together experts from 11 of the 12 snow leopard range countries to order to identify Snow Leopard Conservation Units and knowledge gaps [Jackson et al., 2010]. Such groups can mobilise national protective legislation, namely the international classification of species' status, notably the IUCN/SSC Red Listing process which is vital in the dif- 
ficult task of defining priorities [Mace et al., 2006]. Example outcomes of such species reclassifications include revising the status of the margay to vulnerable (IUCN Cats Red List Workshop 2007), the jaguarundi to near threatened (A3c; IUCN Cats Red List Workshop 2007), and a 2007 Mediterranean Mammal Assessment Workshop classified servals north of the Sahara as regionally critically endangered [Breitenmoser-Wursten et al., 2008]. Another example of a specialist network that spearheads conservation action for a particular species is the Association Européenne pour l'Etude et la Conservation des Lémuriens (AEECL), a consortium of European zoos, which coordinates conservation of Sclater's black lemur alongside local communities. In 2000, the AEECL implemented a natural resource management programme in Sahamalaza to protect the remaining lemur habitat and to improve the living standards of the local human population [Mittermeier et al., 2009]. Similarly, 1992 saw the creation of an International Committee for the Conservation and Management for the Atlantic Forest Capuchin Monkeys, which catalyses conservation of yellow-breasted capuchins and crested capuchins (Cebus robustus), and maintains a captive population of confiscated pets [Kierulff et al., 2008]. The black-bearded saki, beset by local ranchers, timber companies and illegal settlers, benefits from the coordinating efforts of the Primate Protection Centre of the Federal Environmental Protection Institute in Brazil [Veiga et al., 2008b]. Coordinated planning almost always leads to coordinated actions, so, protected by Indonesian law, the pig-tailed langur requires a combination of habitat protection (of the Siberut National Park and Peleonan forest), cooperation with logging companies to promote sustainable extraction, education regarding hunting, and development of alternative economic options for local communities to reduce the sale of land for logging [Whittaker, 2006].

Against this background, where most species face several threats, and there is overlap both within and between the felids and primates in threats and their proposed solutions, an efficient and effective approach could be to seek actions that alleviate the threats to several species in one place. We next review proposed solutions and some of the actions achieved in our primary literature sources and order them in terms of increasing scope for efficiency through shared actions to benefit both felids and primates. Captive breeding and reintroduction, together with combating infectious disease, are likely to deliver largely species-specific solutions, and this may sometimes also be the case for conflict mitigation, conducting surveys and monitoring. However, other solutions, such as regulating and policing trade and protecting habitats, can efficiently benefit multiple species of both taxa. Similarly, education can promote the conservation of several species with the same effort. Interestingly, those solutions, which have the capacity to deliver benefits to several species in the same location, are those which address the threats most commonly recorded as priorities.

\section{Captive Breeding and Reintroduction}

Captive breeding was rather rarely cited as a priority for primates or felids. However, a notable exception amongst felids is breeding Iberian lynx for reintroduction [Wildt et al., 2010]. For primates, captive breeding is mentioned as a solution for bonobos, Lake Alaotra gentle lemurs (Hapalemur alaotrensis) [Andrainarivo et al., 2008d], aye-ayes [Gron, 2007], grey-shanked douc langurs [Ngoc Thanh et al., 2008] 
and the variegated spider monkey [Mittermeier et al., 2009]. There is a small but promising captive breeding programme for the northern muriqui [Mendes et al., 2008]. Captive breeding programmes are not always a viable option, however; the Hainan gibbon Nomascus hainanus is so rare that it is considered too risky to take individuals from the wild into captivity [Geissmann and Bleisch, 2008]. Furthermore, when animals to be reintroduced have been captive bred, changes in the species must be considered in order to maximise the ability of the animals to adapt to their new habitat [IUCN Species Survival Commission, 1987]. When the first captive-bred golden lion tamarins Leontopithecus rosalia were released into their native Atlantic coastal forests of Brazil in 1984, 41\% were lost in the first year, mostly from deficits in finding food, locomotion and orientation [Beck et al., 1991].

The classic example of felid reintroduction is that of the Eurasian lynx in Switzerland, and the aims for progressive re-establishment of a metapopulation in the Alps [Breitenmoser et al., 2010]. Monitoring of released animals is a crucial element of any reintroduction, however, and most of those populations reintroduced since the 1970s have not been monitored. Amongst primates, a new population, now numbering 70 individuals, of the Sumatran orang-utan has been established in the Bukit Tigapuluh National Park using reintroduction of confiscated illegal pets [Singleton et al., 2008]. There is discussion of reintroducing Delacour's langurs (Trachypithecus delacouri) using captive-bred animals [Nadler et al., 2008], and reintroduction of Barbary macaques to Northern Tunisia. It is also a priority to establish a second wild population of Asiatic lion (Panthera leo persica) in the Palpur Kuno Wildlife Sanctuary using lions translocated from the Gir Forest [Jackson, 2008].

\section{Disease}

Amongst the priorities recognised for cheetah conservation were disease surveillance in Kenya, and particularly investigation of scabies and mange and their treatment, while infectious disease has been a threat to lions in the Serengeti [Craft, 2010] and to felids in general [Munson et al., 2010]. There are direct parallels with the threats posed by livestock and human infections to great apes [Walsh, in press] and similar controversies about vaccination interventions.

\section{Surveys}

Although information on distribution may be a foundation for action, it clearly does not deliver conservation in itself. Nonetheless, the incompleteness of data is such that almost every account of the priority actions for conserving felid and primate species includes surveys as a key component. As an example, the Cat Action Plan emphasises the need for surveys of every Asian felid species, generally crossreferring from each to the others with an eye to possible intraguild interactions between them. Thus, surveys are a priority for the Bornean bay cat [Hearn et al., 2008], both species of clouded leopard (especially in southern and south-western China) [Hearn et al., submitted], Asian golden cats, flat-headed cats in Burma, Thailand, Malaysia and Indonesia [Cheyne et al., 2009], and especially the Isthmus of Kra (Burma and Thailand) [Wilting et al., 2010]. There are calls for general surveys of 
rusty spotted cats and fishing cats (which, according to Nekaris [2003] and Duckworth et al. [2005], are disappearing fast from Bharatpur, India, and perhaps have already been lost from south-western India and Pakistan [Mukherjee et al., 2010]), and also marbled cats (there has been some success with camera-trapping in Cambodia [Duckworth et al., 2005] and Indonesia [Cheyne and Macdonald, 2010]).

The priority response to the threats identified for many primate species is also to survey their status. For example, the Hainan gibbon is arguably the most critically endangered primate in the world, and surveys beyond its stronghold in Bawangling Nature Reserve are a priority [Geissmann and Bleisch, 2008]. Similarly urgent calls have been made for surveys of drills, mandrills and bonobos, Miss Waldron's red colobus (of which none was found in the eastern and central Ivory Coast in 2005 [Oates, 1996; McGraw, 2005]), the silky sifaka (with a keen eye to corridors [Mittermeier et al., 1992]), the Sarawak surili [Nijman et al., 2008] and the blonde capuchin.

A rather dismal conclusion from this long list of calls for surveys on distributions (some range wide, some focussed) might be that for many species insufficient information is known to evaluate the problem, or to create a baseline against which to judge interventions. In other cases, more is known, or can readily be deduced, and all too often it is dire. Nonetheless, successful surveys disclosed Diana monkeys in the Dadieso Forest Reserve in Ghana [Mittermeier et al., 2009], new populations of Sclaters guenon, and the western Hoolock gibbon in 30 protected areas in India [Brockelman et al., 2008].

\section{Conflict Mitigation}

Conflict, whether real or perceived, may fuel disharmony, even hatred, between people and wildlife. The conservation steps are to study conflict sufficiently to distinguish the imagined from the real, and to deal with the former through education (see below) and the latter through mitigations and perhaps financial mechanisms; this decision tree is explored in the Biodiversity Impacts Compensation Scheme reviewed by Macdonald and Sillero-Zubiri [2004] and by the Payments to Encourage Conservation schemes described by Dickman et al. [2011]. For species after species, the Cat Action Plan recommends a basket of measures associated with mitigation, such as prioritizing the Snow Leopard Survival Strategy to include grazing practices that reduce the impact of agriculture on wildlife, especially ungulates. Another example is the recommendation of livestock husbandry practices that reduce vulnerability to snow leopard predation. For primates, conflict was less frequently cited as a priority threat to threatened species. As with felids, while solutions may often be somewhat species specific, there are opportunities for shared gains from improved stockmanship and mitigation: in Bhutan the farmers who maintain nocturnal vigils over their fields chase off both tigers and macaques [Wang and Macdonald, 2006].

A noteworthy success for mitigating stock raiding is the use of specialised livestock-guarding dogs which can drastically reduce predation by cheetahs [Marker et al., 2010]. This has been successfully used in combination with cheetah-proof swing gates to keep cheetahs out of critical farmland while allowing access to warthogs, porcupines and aardvarks. The basket of measures developed to conserve Namibian cheetahs in- 
cludes premium-branded cheetah-friendly beef, and the establishment of conservancies (where land owners manage their resources collectively, sharing the risk associated with predators and so reducing persecution). Stock-raiding lions may be translocated instead of killed, or, ingeniously, toxic collars selectively target only problem animals (a capsule of poison on the collar around the neck of livestock kills the predator as it attempts a throat bite). The caracal is classified as a problem animal in Namibia and South Africa, so landowners can kill them freely; however, protective collars show promise as a non-lethal means of control [Macdonald et al., 2010a]. The blame for damage done to crops or livestock may not always be fairly attributed to pest felids or primates. For example, the national forestry department in Morocco contends that there are too many macaques in the region (due to the disappearance of predators such as leopards), and that the macaques damage cedars through bark stripping. As a result, Barbary macaques have been culled or translocated [Deag, 1977]. However, studies have found the macaque population to be in decline and that bark stripping is a result of water or nutrient shortages in their diet [Camperio Ciani et al., 2001].

Topical opinion prioritises financial mechanisms to incentivise communities to tolerate conflict with wildlife, and to give that wildlife value. Approaches vary from compensation for loss to payments for the delivery of conservation services, as reviewed by Bulte et al. [in press], and collectively termed Payments to Encourage Coexistence [Dickman et al., 2011]. Wherever the Cat Action Plan identified conflict as a threat to any species, a priority call was made to devise financial mechanisms to mitigate it. One such was to evaluate for cheetahs the economic use options of trophy hunting, sale of animals for breeding programmes and tourism on game ranches for conservation. For leopards the recommendation was to develop strategies for local people to obtain income from leopards to incentivise them not to persecute these animals. The Ranthambhore Foundation's ecodevelopment project seeks to improve the living standards of local people in the Ranthambhore Tiger Reserve by growing trees for firewood, timber and fodder for livestock, rehabilitating land damaged by farming, providing high-yielding cattle breeds, help with marketing milk, and providing health services and environmental education programmes [Rithe, 2011]. Sufficient schemes have now been tried to evaluate their efficacy [Macdonald and Loveridge, 2010, p. 195]. For example, schemes to compensate stock owners for losses to lions in Botswana [Hemson et al., 2009] and Kenya [Maclennan et al., 2009] have not quelled animosity to lions, whereas payments to Lion Guardians for conserving lions seem promising [Dickman et al., 2011].

There is a call for a scheme to compensate farmers for crop damage by aye-ayes [Mittermeier et al., 2009], but more generally the aim is to integrate conservation and community development, for example combining bonobo conservation with community participation in sustainable use of resources [Fruth et al., 2008]. Proposals for the Pagai Island macaque include sustainable logging and the development of alternative economic models for the local people [Whittaker, 2006], while there are calls for economic models to enable people to develop livelihoods in buffer zones around protected areas established for the Peruvian yellow-tailed woolly monkey [Cornejo et al., 2008; Mittermeier et al., 2009] and for the San Martin titi monkey in Amerindian reservations [Veiga et al., 2011]. The integration of community benefits and livelihoods are diverse, spanning the linkage of Cao-vit crested gibbon conservation in Vietnam to education of local communities to promote sustainability, including rural energy projects that reduce charcoal use, to Proyecto Titi which in- 
volves communities in the protection of the cotton tamarin and wider natural resources [Savage and Causado, 2008].

The principle behind this paper is that there may be efficiencies in conservation interventions across taxa. Compensation for damage done by pest species seems most feasibly to embrace species within taxa (e.g. MacLennan et al. [2009] report a scheme whereby compensation for lion depredations is linked to that by leopards, cheetah and hyenas), and our analysis suggests that conflict with humans is a threat that differs between felids and primates in its frequency and geographic location (online suppl. table 3). Nonetheless across taxa, there could perhaps be linkages between financial instruments to tackle both stock-raiding felids and crop-raiding primates.

\section{Enforcement}

Tightening regulation and its enforcement is a key action for protecting threatened primates and felids. When enforcement fails so too does the intended consequence of the original law. For example in October 2007, a presidential decree banning the hunting and possession of primates in Equatorial Guinea was signed. For a few months after the signing of the decree, the killing of monkeys on Bioko was reduced by more than $95 \%$. The decree was, however, never effectively enforced, and by early 2009 the number of monkeys killed was back to pre-October 2007 levels [Butynski et al., in press]. Conversely, a miscellany of successful enforcement of regulations includes the protection of jungle cats in Afghanistan from all hunting and trading under Afghanistan's 2009 Protected Species List [Duckworth et al., 2008], as well as the protection of the African wildcat [Driscoll and Nowell, 2009] and the Asiatic cheetah [Durant et al., 2008], which is also protected in Iran (notably in the Kavir National Park, Khar Touran National Park and Naybandan Wildlife Refuge, Bafgh P.A., and Dar Anjir Wildlife Refuge). Priority action for snow leopard conservation includes strengthening local, regional and national legislation that prohibits hunting, possession and trade in snow leopards, and improving enforcement [Theile, 2003]. Similarly, primate species action plans repeatedly emphasise the importance of enforcement. Orang-utans are strictly protected under Indonesian domestic legislation, and the Indonesian government has developed a National Strategy and Action Plan for Orang-Utan Conservation between 2007 and 2017. Actions include implementing patrols, improving law enforcement (especially the number and frequency of cases prosecuted), stopping illegal and legal logging, stopping road construction and forest conversion to plantations, promoting forest restoration, addressing human-orang-utan conflict and increasing connectivity for orang-utans through their habitat [Mittermeier et al., 2009]. Other specific conservation recommendations that will require strict enforcement to be successful include an immediate ban on shotgun hunting of Pennant's red colobus, plus the confiscation of all shotguns on Bioko Island [Hearn et al., 2006]. There are calls for similar enforcement to help the northern white-cheeked gibbon [Bleisch et al., 2008a], the Javan slow loris [Nekaris and Shekelle, 2008], the grey-shanked douc langur [Long, 2004] and Barbary macaques [Butynski et al., 2008]. A typical example of where legislation exists but is not enforced sufficiently is the case of Delacour's langur, which occurs in 6 protected areas but is still heavily hunted. With conflict, as with other common threats, synergistic approaches across species and taxa may be of value, potentially by identifying 
relatively few areas which should be rigorously enforced with hefty lobbying from both cat and primate conservationists. A wildlife law enforcer would often be able, at no additional cost, to deliver results across, inter alia, felids and primates.

\section{Trade}

Similar efficiencies in the conservation of both felids and primates are surely attainable under the heading of trade. For felids, the issues related to trade fall into two broad categories; the sale of body parts for Asian traditional medicine and the sale of skins. Although most countries banned tiger trade in 1993, regulation is insufficient and thus the Cat Action Plan listed evaluating the effectiveness of trade bans on tiger bone medicines in China, Taiwan and South Korea as a priority conservation action. There has been legislation to curtail the trade of felid skins. For example hunting Eurasian lynx for commercial purposes (other than sport hunting) is permitted by only one (Russia) of the range states in which it is found [Breitenmoser et al., 2008]. However, for several species enforcement of trade restrictions, like legislation to protect these species in general, appears inadequate. Leopards need better protection (especially in Indo-Malaya and China) [Nowell, 2007] as do jungle cats [Duckworth et al., 2008] and snow leopards [Wingard and Zahler, 2006].

A widespread priority for primates is legislation and education to staunch trade in bushmeat. This is mentioned specifically in conservation plans for bonobos [Fruth et al., 2008], the Lake Alaotra gentle lemur [Andrainarivo et al., 2008d], silky sifaka [Andrainarivo et al., 2008] and Javan slow loris [Nekaris and Shekelle, 2008]. In Laos, heavy fines have been set for wildlife trade, and gun controls have been put in place to protect the black-crested gibbon from hunting [Johnson et al., 2005].

\section{Habitat Protection}

It is easier to call for new protected habitat than to deliver it. In the actions and outcomes reported thus far in the Cat Action Plan and associated literature, we found no cases of new protected areas created in response to the numerous calls for felid protection. A characteristic example would be the prioritised action of supporting the Arabian Leopard Trust in its work to lobby government for reserve creation (along with legal prohibition of hunting, public education, improving management of captive cat populations, etc). In the context of habitat protection, the most frequent proposed conservation action is the scoping and creation of corridors to link subpopulations in constellations. This is, for example, proposed as a top priority for African lions (in association with habitat restoration, conflict mitigation and financial incentives), and also specifically for the South China and Amur tiger and for jaguars [Rabinowitz, 2007].

Review of our core literature reveals that several protected areas have been established, to the benefit of primates. For example, part of the island of Superagüi was decreed a national park in 1989 for the black-faced lion tamarin Leontopithecus caissara, and part of the range of Sclater's black lemur was included in the Parc National Sahamalaza Iles Radama in 2007 [Mittermeier et al., 2009], while the cotton top tamarin has been protected in Colombia since 1969 [Savage and Causado, 2008], 
where it occurs in 3 protected areas and a national park; the yellow-breasted capuchin is protected in the Una Biological Reserve and, decreed in 2008, the Serra da Lontras National Park. Lac Alaotra was declared a Ramsar site in 2003 for the Lake Alaotra gentle lemur [Andrainarivo et al., 2008d]. However, while the obvious response to the threat of habitat loss is to call for protected areas, the literature review reveals these calls are often not heeded. The Niger Delta red colobus has no protected area, a plan to create one having been thwarted by political instability [Werre, 2000], as was the case for the now possibly extinct Miss Waldron's red colobus in south-eastern Ivory Coast [McGraw, 2005; Oates, 2011]. A 5-year project to monitor the Tana River red colobus was begun in 1996 to conserve and protect the primates and the gallery forests, but this project floundered due to poor management [Mittermeier et al., 2009].

Habitat loss arises for various reasons, and our review revealed that there were both similarities and differences between the specific categories of habitat loss attributed as threats to some threatened felids and primates. These differences merit further scrutiny, at a finer scale than our $1^{\circ} \times 1^{\circ}$ grid. Some identified causes of habitat loss may reflect fine-scale reality, others might be influenced by the perceptions of biologists accustomed to working at different scales with one or other of the two taxa, such that a primatologist's agricultural encroachment may be a felid biologist's habitat fragmentation.

\section{Education}

There are innumerable education schemes to change perceptions of felids and primates as an aid to their conservation. Notable examples include the school booklets that demystify jaguars, with associated studies of perception and influence [Marchini and Macdonald, 2012], topics reviewed more widely by Dickman et al. [in press]. For primates, community education has been instigated for the Lake Alaotra gentle lemur [Andrainarivo et al., 2008d], the gray-headed lemur (in association with community tree-planting schemes [Mittermeier et al., 2009]), and debunking myths that aye-ayes are harbingers of bad luck. Barbary macaques have benefitted from public education campaigns against illegal trade, commercial uses of monkeys and improper artificial feeding run by an Algerian ecology organisation collaborating with various other organisations. An innovative example is the use of theatre groups of local people to perform conservation plans to local children, for example performing tribal dramas explaining conflict with lions to villagers in Zimbabwe [Macdonald and Burnham, 2011]. The impact of education is hard to measure, but there has been a reduction in livestock depredation by snow leopards in the Annapurna Conservation Area, Nepal, through educating herders on improving livestock guarding (against the background of establishing snow leopards as a tourist attraction and thus providing income for local people). Further examples include attempts to use education to reduce illegal hunting of Iberian lynx in Spain and Andean cats [Lucherini et al., 2003; Villalba et al., 2012], and to avoid accidental by-catch of Canada lynx [Golden and Krause, 2003].

The importance of grass roots initiatives and community engagement to the success of conservation efforts cannot be overstated. For example, including locals in conservation meetings in the Pantanal, Brazil, has been credited for the positive 
perception of jaguar conservation activities [Rabinowitz, 2005]. Jackson and Wangchuk [2001] used Appreciative Participatory Planning and Action to encourage group action to reduce livestock loss and associated retaliatory killing of snow leopards in Markha Valley, Hemis National Park, India. They propose that communitybased stewardship, where local people benefit from the presence of wildlife, is the most cost-effective approach, as well as the one most likely to succeed [Jackson and Wangchuk, 2001]. Simple measures, such as improving livestock husbandry and finding ways for locals to benefit financially from protecting snow leopards through opening tea houses for the ecotourism trade, have proved successful thus far [Jackson et al., 2010].

\section{Conclusions}

There is overlap in the distributions of many threatened species and this is especially true of many threatened mammals. In the interests of efficiency, and perhaps also exploiting the umbrella concept, there are therefore many opportunities to look for, and capitalise upon, ubiquitous solutions to shared threats. Both threatened felids and primates have global distributions that overlap widely. Felids and primates interact as predators and prey, are highly valued and charismatic but also, at least sometimes, are in conflict with people. Crucially, both taxa include numerous threatened species. Furthermore, amongst carnivore families, felids are the most uniformly and dedicatedly carnivorous, which gives them relatively large range sizes for their body masses, and hence arguably added potential as umbrella species. Our review supports the general proposition that felids and primates face many of the same threats, and spatially, albeit at a coarse scale, we illustrate that these threats often affect both taxa in similar locations. If habitat loss were to be prevented for the clouded leopard, for example, then there are a multitude of primates and other felids also threatened by habitat loss that would potentially benefit from this conservation action (table 4).

Furthermore, threats commonly occur as linked syndromes, for example habitat loss, degradation and fragmentation are associated with bushmeat hunting and by-catch. Although the distributions of some threatened species of each taxon do not overlap with any threatened species of the other taxon, there are sufficient coarse overlaps (a maximum combined total of species in one grid cell being 14), to make it sensible to look for efficiencies that might be achieved by applying solutions that ubiquitously benefit both taxa. Of the global area where threatened species of either taxon are found, a quarter (24.7\%) contains at least 1 species of each, so there is potential for ubiquitous conservation action plans in these regions that would be beneficial to both felid and primate species. This is further emphasised by the fact that $75 \%$ of threatened felids and threatened primates co-occur with up to 4 species, where there is at least 1 species of each taxon present. In addition, table 1 illustrates the potentially large pay-offs of a multitaxon approach to conservation. By conserving the $15 \%$ of the felid range that includes those felid and primate species threatened by habitat loss, then it would also conserve $70 \%$ of all primates facing this threat. For $15 \%$ of the distribution of felids threatened by hunting, $65 \%$ of the distribution of all primates facing this threat would also be conserved. This umbrella effect is most pronounced in Africa, where there are many species of both taxa that suffer from the same or similar suite of threats. 
Table 4. The primate and felid species facing the threat of habitat loss that may benefit from conservation action to protect clouded leopards from habitat loss

\begin{tabular}{|c|c|}
\hline Species name & Common name \\
\hline \multicolumn{2}{|l|}{ Primates } \\
\hline Macaca arctoides & Stump-tailed macaque \\
\hline Macaca assamensis & Assam macaque \\
\hline Macaca leonina & Northern pig-tailed macaque \\
\hline Macaca nemestrina & Southern pig-tailed macaque \\
\hline Macaca thibetana & Milne-Edwards' macaque \\
\hline Presbytis femoralis & Banded surili \\
\hline Presbytis siamensis & White-thighed surili \\
\hline Pygathrix nemaeus & Red-shanked douc langur \\
\hline Pygathrix nigripes & Black-shanked douc langur \\
\hline Rhinopithecus bieti & Black snub-nosed monkey \\
\hline Rhinopithecus roxellana & Golden snub-nosed monkey \\
\hline Semnopithecus hector & Tarai grey langur \\
\hline Trachypithecus germaini & Indochinese lutung \\
\hline Trachypithecus obscurus & Dusky leaf monkey \\
\hline Trachypithecus phayrei & Phayre's leaf monkey \\
\hline Trachypithecus pileatus & Capped langur \\
\hline Trachypithecus shortridgei & Shortridge's langur \\
\hline Hoolock hoolock & Western hoolock gibbon \\
\hline Hoolock leuconedys & Eastern hoolock gibbon \\
\hline Hylobates agilis & Agile gibbon \\
\hline Hylobates lar & Lar gibbon \\
\hline Hylobates pileatus & Pileated gibbon \\
\hline Nomascus concolor & Black crested gibbon \\
\hline Nomascus gabriellae & Red-cheeked gibbon \\
\hline Nomascus leucogenys & Northern white-cheeked gibbon \\
\hline Nomascus siki & Southern white-cheeked gibbon \\
\hline Symphalangus syndactylus & Siamang \\
\hline Nycticebus bengalensis & Bengal slow loris \\
\hline Nycticebus coucang & Greater slow loris \\
\hline Nycticebus pygmaeus & Pygmy slow loris \\
\hline \multicolumn{2}{|l|}{ Felids } \\
\hline Otocolobus manul & Manul \\
\hline Panthera tigris & Tiger \\
\hline Panthera uncia & Snow leopard \\
\hline Pardofelis marmorata & Marbled cat \\
\hline Pardofelis temminckii & Asiatic golden cat \\
\hline Prionailurus viverrinus & Fishing cat \\
\hline
\end{tabular}

We acknowledge that our analysis is conducted at a coarse scale, based on overlaying the distribution maps, plotted at the resolution of $1^{\circ} \times 1^{\circ}$ cells, for each species' geographic range. At this level of resolution, species of either or both threatened panels that co-occur in a grid cell do so in the approximate sense that their distributions both encompass that cell. This level of co-occurrence is not evidence that they 
occur in exactly the same locations. Furthermore, when 2 co-occurring species are identified as facing, as a priority, the same threat, this is not firm evidence that they both face it in the same places, although it seems plausible that they will do so (at the level of ecoregions, we have shown in fig. 7 some congruence in the threats faced by the two taxa). Acknowledging these scale-based caveats, and having demonstrated the scope for efficiencies in the species-based conservation of felids and primates, we suggest that it would be more fruitful to explore these synergies at a much finer resolution. Furthermore, we consider only where species co-occur and face the same threats. A more detailed investigation should also consider factors such as body size, stratum occupied (arboreal/terrestrial) and daily activity cycle (diurnal/nocturnal). These traits are likely to affect interspecific interactions (including predator-prey relationships), and also the likelihood that conservation actions will benefit both focal species and those that are protected beneath its 'umbrella'.

Our review raises several questions for future research. Are the distributions of co-occurring threatened felids and primates merely a reflection of mammalian biodiversity linked to tropical forest habitats, or do they reflect some other biogeographical or perhaps purely biological process? The answer does not diminish their potential value to conservation planning, but may reveal interesting processes that better inform conservation plans. Similarly, are these felid-primate hotspots congruent with other spatial prioritisation systems for conservation, and if not, why not? Figure $2 \mathrm{~b}$ reveals that although some of the felid-primate hotspots are captured by CI hotspots, some $60 \%$ of those that contain at least 1 species each of endangered felid and primate are not. This raises the question of whether there are differences between those felidprimate hotspots that do, and do not, overlap CI hotspots. For example, our analysis has not distinguished endemic species from others that are threatened, whereas endemism is a criterion in CI hotspots. There are many ways to identify areas to prioritise for conservation action, partly because data limitations currently preclude the measurement of overall biodiversity. Only poor-quality data are available on what species exist, where they occur and the accurate cost estimates of protecting them. One of the future challenges for prioritisation analyses is to find ways of compensating for missing data [Arponen, 2012]. One way of selecting priority areas for conservation that takes a different approach to CI hotspots, or our felid-primate hotspots, is that of Cardillo et al. [2006], where they highlight species whose biological traits make them especially vulnerable to future human impact, but which are not yet at the stage of being officially threatened because the human impact is currently low. Another approach is that taken by Rodrigues et al. [2004], who identify regions of the world not currently covered by protected areas (the aim of which is to maximise global biodiversity) but yet have very high conservation value and are seriously threatened. Brooks et al. [2006] review 9 templates of global priorities, including 'crisis ecoregions' and 'endemic bird areas'. Some of these 9 different approaches they class as reactive (prioritizing high vulnerability, so selecting areas where biodiversity loss is imminent without conservation action), and others as pro-active (prioritising low vulnerability, so selecting areas that have greater conservation opportunities). Whether alternative strategies are pro-active or reactive has a notable effect on which regions are selected for conservation and also the size of the areas designated as priority regions. Most of the approaches reviewed by Brooks et al. [2006] also prioritise high irreplaceability (high levels of endemism). Habitat loss, as an environmental and spatial variable that measures species vulnerability, is often used in prioritisation analy- 
ses, although it is potentially flawed for being retrospective rather than predictive in nature [Brooks et al., 2006]. Other measures included in prioritisation analyses are protected area status, human population density and vulnerability to climate change [Summers et al., 2012], carbon storage and deforestation rates [Buchanan et al., 2011]. However, none of the 9 main templates reviewed by Brooks et al. [2006] used threatened species as a criterion, and thus the felid-primate approach proposed in this paper adds another perspective to conservation prioritisation.

A more detailed threat classification system, comparable within and across taxa assessments, identifying dominant threats as well as direct and indirect drivers, would aid conservation planning. A well-designed system could incorporate scale metrics, inter alia, and therefore better feed evidence-based evaluation of conservation interventions and strategies as propounded by Sutherland et al. [2004] but thus far rarely available [Macdonald et al., 2011; Howe and Milner-Gulland, 2012].

Our analyses focus solely on felids and primates, but there are other, more efficient bundles of taxa (perhaps primates might be efficiently conserved alongside a basket of large terrestrial mammals, which are a grouping that Macdonald et al. [2013] argue share conservation attributes).

There is already considerable mutual support between individuals working on different taxa at the ground level, although it is often of a more informal nature. Our results raise the question of what opportunities exist, either practically or at the policy-making level of non-governmental organisations and governments, to strategically enhance conservation efficiency. A simple strategy would be to consider cooccurrence, and combine opportunities, before implementing new actions.

\section{Acknowledgments}

We thank Lucy Tallents for help with GIS, Paul Johnson for help with statistical analysis and Tom Moorhouse and Marion Valeix for critical comments on this manuscript (together with those of two anonymous referees). Tom Butynski and Jonathan Kingdon generously allowed us to review threats identified in the unpublished primate volume of MOA. We thank the Recanati-Kaplan Foundation, the Robertson Foundation and the Woodspring Trust for their support.

\section{References}

Acosta G, Cossios D, Lucherini M, Villalba L (2008). Leopardus jacobita. In IUCN Red List of Threatened Species. Version 2011.1. http://www.iucnredlist.org.

Acosta G, Lucherini M (2008). Leopardus guigna. In IUCN Red List of Threatened Species. Version 2011.1. http://www.iucnredlist.org.

Ancrenaz M, Marshall A, Goossens B, van Schaik C, Sugardjito J, Gumal M, Wich S (2008). Pongo pygmaeus. In IUCN Red List of Threatened Species. Version 2011.1. http://www.iucnredlist.org.

Andrainarivo C, Andriaholinirina VN, Feistner A, Felix T, Ganzhorn J, Garbutt N, Golden C, Konstant B, Louis E Jr, Meyers D, Mittermeier RA, Patel E, Perieras A, Princee F, Rabarivola JC, Rakotosamimanana B, Rasamimanana H, Ratsimbazafy J, Raveloarinoro G, Razafimanantsoa A, Rumpler Y, Schwitzer C, Thalmann U, Wilmé L, Wright P (2008a). Propithecus candidus. In IUCN Red List of Threatened Species. Version 2011.1. http://www.iucnredlist.org.

Andrainarivo C, Andriaholinirina VN, Feistner A, Felix T, Ganzhorn J, Garbutt N, Golden C, Konstant B, Louis E Jr, Meyers D, Mittermeier RA, Perieras A, Princee F, Rabarivola JC, Rakotosamimanana B, Rasamimanana H, Ratsimbazafy J, Raveloarinoro G, Razafimanantsoa A, Rumpler Y, Schwitzer C, Sussman R, Thalmann U, Wilmé L, Wright P (2011). Eulemur flavifrons. In IUCN Red List of Threatened Species. Version 2011.1. http://www.iucnredlist.org. 
Andrainarivo C, Andriaholinirina VN, Feistner A, Felix T, Ganzhorn J, Garbutt N, Golden C, Konstant B, Louis E Jr, Meyers D, Mittermeier RA, Perieras A, Princee F, Rabarivola JC, Rakotosamimanana B, Rasamimanana H, Ratsimbazafy J, Raveloarinoro G, Razafimanantsoa A, Rumpler Y, Schwitzer C, Thalmann U, Wilmé L, Wright P (2008b). Lepilemur septentrionalis. In IUCN Red List of Threatened Species. Version 2011.1. http://www.iucnredlist.org.

Andrainarivo C, Andriaholinirina VN, Feistner A, Felix T, Ganzhorn J, Garbutt N, Golden C, Konstant B, Louis E Jr, Meyers D, Mittermeier RA, Perieras A, Princee F, Rabarivola JC, Rakotosamimanana B, Rasamimanana H, Ratsimbazafy J, Raveloarinoro G, Razafimanantsoa A, Rumpler Y, Schwitzer C, Thalmann U, Wilmé L, Wright P (2008c). Daubentonia madagascariensis. In IUCN Red List of Threatened Species. Version 2011.1. http://www.iucnredlist.org.

Andrainarivo C, Andriaholinirina VN, Feistner A, Felix T, Ganzhorn J, Garbutt N, Golden C, Konstant B, Louis E Jr, Meyers D, Mittermeier RA, Perieras A, Princee F, Rabarivola JC, Rakotosamimanana B, Rasamimanana H, Ratsimbazafy J, Raveloarinoro G, Razafimanantsoa A, Rumpler Y, Schwitzer C, Thalmann U, Wilmé L, Wright P (2008d). Hapalemur alaotrensis. In IUCN Red List of Threatened Species. Version 2011.1. http://www.iucnredlist.org.

Arponen A (2012). Prioritizing species for conservation planning. Biodiversity and Conservation 21: 875-893.

Balme GA, Slotow R, Hunter LTB (2010). Edge effects and the impact of non-protected areas in carnivore conservation: leopards in the Phinda-Mkhuze Complex, South Africa. Animal Conservation 13: 315-323.

Barrett CB, Bulte EH, Ferraro P, Wunder S (2013). Economic instruments for nature conservation. In Key Topics in Conservation Biology, vol. 2 (Macdonald DW, Willis KJ, eds.). Oxford, Wiley-Blackwell.

Barrett MA, Ratsimbazafy J (2009). Luxury bushmeat trade threatens lemur conservation. Nature 461: 470-470.

Beck BB, Kleiman DG, Dietz JM, Castro MI, Carvalho C, Martins A, Rettberg-Beck B (1991). Losses and reproduction in reintroduced golden lion tamarins (Leontopithecus rosalia). The Dodo, Journal of the Jersey Wildlife Preservation Trust 27: 55-61.

Bicca-Marques JC (2009). Outbreak of yellow fever affects howler monkeys in southern Brazil. Oryx 43: 173.

Bleisch B, Geissmann T (2008). Nomascus nasutus. In IUCN Red List of Threatened Species. Version 2011.2. http://www.iucnredlist.org.

Bleisch B, Geissmann T, Manh Ha N, Rawson B, Timmins RJ (2008a). Nomascus leucogenys. In IUCN Red List of Threatened Species. Version 2011.2. http://www.iucnredlist.org.

Bleisch B, Geissmann T, Timmins RJ, Xuelong J (2008b). Nomascus concolor. In IUCN Red List of Threatened Species. Version 2011.1. http://www.iucnredlist.org.

Bleisch B, Xuan Canh L, Covert B, Yongcheng L (2008c). Trachypithecus poliocephalus. In IUCN Red List of Threatened Species. Version 2011.1. http://www.iucnredlist.org.

Boonratana R, Xuan Canh L (1998). Conservation of Tonkin snub-nosed monkeys [Rhinopithecus (Presbyticus) avunculus] in Vietnam. In The Natural History of the Doucs and Snub-Nosed Monkeys (Jablonsky NG, ed.), pp 207-215. Singapore, World Scientific Publishing.

Breitenmoser U, Mallon DP, von Arx M, Breitenmoser-Wursten C (2008). Lynx lynx. In IUCN Red List of Threatened Species. Version 2011.1. http://www.iucnredlist.org.

Breitenmoser U, Ryser A, Molinari-Jobin A, Zimmerman F, Haller H, Molinari P, Breitenmoser-Wursten $C$ (2010). The changing impact of predation as a source of conflict between hunters and reintroduced lynx in Switzerland. In Biology and Conservation of Wild Felids (Macdonald DW, Loveridge AJ, eds.), pp 493-506. Oxford, Oxford University Press.

Breitenmoser-Wursten C, Henschel P, Sogbohossou E (2008). Leptailurus serval. In IUCN Red List of Threatened Species. Version 2011.1. http://www.iucnredlist.org.

Brockelman W, Molur S, Geissmann T (2008). Hoolock hoolock. In IUCN Red List of Threatened Species. Version 2011.2. http://www.iucnredlist.org.

-Brooks TM, Mittermeier RA, da Fonseca GAB, Gerlach J, Hoffmann M, Lamoreux JF, Mittermeier CG, Pilgrim JD, Rodrigues ASL (2006). Global biodiversity conservation priorities. Science 313: 58-61.

Buchanan GM, Donald PF, Butchart SHM (2011). Identifying priority areas for conservation: a global assessment for forest-dependent birds. Plos One 6: e29080.

- Burnham D, Bearder SK, Cheyne SM, Dunbar RIM, Macdonald DW (2012a). Predation by mammalian carnivores on nocturnal primates: is the lack of evidence support for the effectiveness of nocturnality as an antipredator strategy? Folia Primatologica 83:236-251.

Burnham D, Hinks AE, Macdonald DW (2012b). Life and dinner under the shared umbrella: patterns in felid and primate communities. Folia Primatologica 83:148-170.

Butynski TM, Cortes J, Waters S, Fa J, Hobbelink ME, van Lavieren E, Belbachir F, Cuzin F, de Smet K, Mouna M, de Iongh H, Menard N, Camperio-Ciani A (2008). Macaca sylvanus. In IUCN Red List of Threatened Species. Version 2011.1. http://www.iucnredlist.org. 
Butynski TM, Kalina J (1998). Gorilla tourism: a critical look. In Conservation of Biological Resources (Milner-Gulland EJ, Mace R, eds.), pp 280-300. Oxford, Blackwell Science.

Butynski TM, Kingdon J, Kalina J (eds.) (in press). The Mammals of Africa, vol II: Primates. London, Bloomsbury.

-Camperio Ciani A, Martinoli L, Capiluppi C, Arahou M, Mouna M (2001). Effects of water availability and habitat quality on bark-stripping behavior in Barbary macaques. Conservation Biology 15: 259-265.

Carbone C, Mace G, Roberts SC, Macdonald DW (1999). Energetic constraints on the diet of terrestrial carnivores. Nature 402: 286-288.

Cardillo M, Mace GM, Gittleman JL, Purvis A (2006). Latent extinction risk and the future battlegrounds of mammal conservation. Proceedings of the National Academy of Sciences of the United States of America 103: 4157-4161.

Carvalho O Jr, de Pinto ACB, Galetti M (1999). New observations on Cebus kaapori in eastern Brazilian Amazonia. Neotropical Primates 7: 41-43.

Caso A, Lopez-Gonzalez C, Payan E, Eizirik E, de Oliveira T, Leite-Pitman R, Kelly M, Valderrama C (2008). Panthera onca. In IUCN Red List of Threatened Species. Version 2011.1. http://www. iucnredlist.org.

Cheyne SM, Macdonald DW (2010). Confirmed presence of marbled cat in Sabangau peat-swamp forest, Indonesian Borneo. Cat News 52: 11.

Cheyne SM, Morrogh-Bernard H, Macdonald DW (2009). First flat-headed cat from Sabangau peatswamp forest, Indonesian Borneo. Cat News 51: 18.

Chundawat RS, Habib B, Karanth U, Kawanishi K, Ahmad Khan J, Lynam T, Miquelle D, Nyhus P, Sunarto S, Tilson R, Wang S (2010). Panthera tigris. In IUCN Red List of Threatened Species. Version 2011.1. http://www.iucnredlist.org.

Cochrane A (1972). Effectiveness and Efficiency. Random Reflections on the Health Service. London, Nuffield Provincial Hospitals Trust.

Collins MB, Milner-Gulland EJ, Macdonald EA, Macdonald DW (2011). Pleiotropy and charisma determine winners and losers in the REDD+ game: all biodiversity is not equal. Tropical Conservation Science 4: 261-266.

Collins NM, Sayer JA, Whitmore TC (1991). The Conservation Atlas of Tropical Forests: Asia and the Pacific. Gland, IUCN.

Cornejo F, Rylands AB, Mittermeier RA, Heymann E (2008). Oreonax flavicauda. In IUCN Red List of Threatened Species. Version 2011.1. http://www.iucnredlist.org.

Craft ME (2010). Ecology of infectious diseases in Serengeti lions. In Biology and Conservation of Wild Felids (Macdonald DW, Loveridge AJ, eds.), pp 263-282. Oxford, Oxford University Press.

Davenport TRB, Jones T (2008). Rungwecebus kipunji. In IUCN Red List of Threatened Species. Version 2011.1. http://www.iucnredlist.org.

De Oliveira MM, Boubli J-P, Kierulff MCM (2008a). Cebus flavius. In IUCN Red List of Threatened Species. Version 2011.1. http://www.iucnredlist.org.

De Oliveira T, Eizirik E, Schipper J, Valderrama C, Leite-Pitman R, Payan E (2008b). Leopardus tigrinus. In IUCN Red List of Threatened Species. Version 2011.1. http://www.iucnredlist.org.

Deag JM (1977). The status of the Barbary macaque Macaca sylvanus in captivity and factors influencing its distribution in the wild. In Primate Conservation (Prince Rainier III of Monaco, Bourne GH, eds.), pp 267-287. New York, Academic Press.

Dickman AJ, Macdonald EA, Macdonald DW (2011). A review of financial instruments to pay for predator conservation and encourage human-carnivore coexistence. Proceedings of the National Academy of Sciences of the United States of America 108: 19836-19836.

Dickman AJ, Marchini S, Manfredo M (2013). The importance of the human dimension in addressing conflict with large carnivores. In Key Topics in Conservation Biology, vol. 2 (Macdonald DW, Willis KJ, eds.). Oxford, Wiley-Blackwell.

Driscoll C, Nowell K (2009). Felis silvestris. In IUCN Red List of Threatened Species. Version 2011.1. http://www.iucnredlist.org.

Duckworth JW, Poole CM, Tizard RJ, Walston JL, Timmins RJ (2005). The jungle cat Felis chaus in Indochina: a threatened population of a widespread and adaptable species. Biodiversity and Conservation 14: $1263-1280$.

Duckworth JW, Steinmetz R, Sanderson J, Mukherjee S (2008). Felis chaus. In IUCN Red List of Threatened Species. Version 2011.1. http://www.iucnredlist.org.

Durant S, Marker L, Purchase N, Belbachir F, Hunter L, Packer C, Breitenmoser-Wursten C, Sogbohossou E, Bauer H (2008). Acinonyx jubatus. In IUCN Red List of Threatened Species. Version 2011.1. http://www.iucnredlist.org.

Emmons LH (1987). Comparative feeding ecology of felids in a neotropical rain-forest. Behavioral Ecology and Sociobiology 20: 271-283. 
Formenty P, Boesch C, Wyers M, Steiner C, Donati F, Dind F, Walker F, Le Guenno B (1999). Ebola virus outbreak among wild chimpanzees living in a rain forest of Côte d'Ivoire. Journal of Infectious Disease 179: S130-S136.

Fruth B, Benishay JM, Bila-Isia I, Coxe S, Dupain J, Furuichi T, Hart J, Hart T, Hashimoto C, Hohmann G, Hurley M, Ilambu O, Mulavwa M, Ndunda M, Omasombo V, Reinartz G, Scherlis J, Steel L, Thompson J (2008). Pan paniscus. In IUCN Red List of Threatened Species. Version 2011.1. http:// www.iucnredlist.org.

Geissmann T, Bleisch W (2008). Nomascus hainanus. In IUCN Red List of Threatened Species. Version 2011.1. http://www.iucnredlist.org.

Geissmann T, Xuan Dang N, Lormée N, Momberg F (2000). Vietnam Primate Conservation Status Review 2000. Part 1: Gibbons. Hanoi, Fauna \& Flora Int, Indochina Programme.

Golden H, Krause T (2003). How to avoid incidental take of lynx while trapping or hunting bobcats and other furbearers. US Fish and Wildlife Service.

Gron K (2007). Primate factsheets: aye-aye (Daubentonia madagascariensis) taxonomy, morphology and ecology. http://pin.primate.wisc.edu/factsheets.

Hart D (2007). Predation on primates: a biogeographical analysis. In Primate Anti-Predator Strategies (Gursky SL, Nekaris KAI, eds.), pp 27-59. New York, Springer.

Hearn A, Sanderson J, Ross J, Wilting A, Sunarto S (2008). Pardofelis badia. In IUCN Red List of Threatened Species. Version 2011.1. http://www.iucnredlist.org.

Hearn AJ, Ross J, Pamin D, Bernard H, Hunter L, Macdonald DW (submitted). The consequences of forest management for the Sunda clouded leopard in Sabah, Malaysian Borneo. Journal of Mammalogy.

Hearn G, Morra WA, Butynski TM (2006). Monkeys in Trouble: The Rapidly Deteriorating Conservation Status of the Monkeys on Bioko Island, Equatorial Guinea. Glenside, Bioko Biodiversity Protection Program.

Hemson G, Maclennan S, Mills G, Johnson P, Macdonald D (2009). Community, lions, livestock and money: a spatial and social analysis of attitudes to wildlife and the conservation value of tourism in a human-carnivore conflict in Botswana. Biological Conservation 142: 2718-2725.

Henschel P, Hunter LTB, Coad L, Abernethy KA, Muhlenberg M (2011). Leopard prey choice in the Congo Basin rainforest suggests exploitative competition with human bushmeat hunters. Journal of Zoology 285: 11-20.

Hill C, Wallace G (2012). Crop protection and conflict mitigation: reducing the costs of living alongside non-human primates. Biodiversity and Conservation: 1-19.

Hohmann G, Fruth B (2008). New records on prey capture and meat eating by bonobos at Lui Kotale, Salonga National Park, Democratic Republic of Congo. Folia Primatologica 79: 103-110.

Howe C, Milner-Gulland EJ (2012). Evaluating indices of conservation success: a comparative analysis of outcome- and output-based indices. Animal Conservation 15: 217-226.

Huijbregts B, De Wachter P, Obiang LSN, Akou ME (2003). Ebola and the decline of gorilla Gorilla gorilla and chimpanzee Pan troglodytes populations in Minkebe Forest, north-eastern Gabon. Oryx 37: 437-443.

IUCN (2011). IUCN Red List of Threatened Species. Version 2011.1. http://www.iucnredlist.org.

IUCN Species Survival Commission (1987). IUCN position statement on translocation of living organisms. Gland, IUCN.

Jackson P (2008). Nearly one-tenth of last Asiatic lions died this year. Cat News 47: 36-37.

Jackson R, Mishra C, McCarthy TM, Ale SB (2010). Snow leopards, conflict and conservation. In Biology and Conservation of Wild Felids (Macdonald DW, Loveridge AJ, eds.), pp 417-430. Oxford, Oxford University Press.

Jackson R, Wangchuk R (2001). Linking snow leopard conservation and people wildlife conflict resolution: grassroots measures to protect the endangered snow leopard from herder retribution. Endangered Species Update 18: 138-141.

Johnson A, Singh S, Duangdala M, Hedemark M (2005). The western black crested gibbon Nomascus concolor in Laos: new records and conservation status. Oryx 39: 311-317.

Johnson PJ, Kansky R, Loveridge AJ, Macdonald DW (2010). Size, rarity and charisma: valuing African wildlife trophies. Plos One 5: e12866.

Karanth KU, Stith BM (1999). Prey depletion as a critical determinant of tiger population viability. In Riding the Tiger: Tiger Conservation in Human-Dominated Landscapes (Seidensticker J, Christie S, Jackson P, eds.), pp 100-113. Cambridge, Cambridge University Press.

Kelly M, Caso A, Lopez Gonzalez C (2008). Lynx rufus. In IUCN Red List of Threatened Species. Version 2011.1. http://www.iucnredlist.org.

Kierulff MCM, Mendes SL, Rylands AB (2008). Cebus xanthosternos. In IUCN Red List of Threatened Species. Version 2011.1. http://www.iucnredlist.org.

Kitchener AC, Yasuma S, Andau M, Quillen P (2004). Three bay cats from Borneo. Mammalian Biology Zeitschrift fur Säugetierkunde 69: 349-353. 
Kormos R, Boesch C, Bakarr MI, Butynski TM (2003). West African Chimpanzees: Status Survey and Conservation Action Plan. Gland and Cambridge, IUCN/SSC Primate Specialist Group..

Long HT (2004). Distribution and status of grey-shanked douc langur (Pygathrix cinerea) in Vietnam. In Conservation of Primates in Vietnam (Nadler T, Streicher U, Ha Thang L, eds.), pp 52-57. Hanoi, Frankfurt Zoological Society.

Loveridge AJ, Hemson G, Davidson Z, Macdonald DW (2010). African lions on the edge: reserve boundaries as 'attractive sinks'. In Biology and Conservation of Wild Felids (Macdonald DW, Loveridge AJ, eds.), pp 283-304. Oxford, Oxford University Press.

Loveridge AJ, Searle AW, Murindagomo F, Macdonald DW (2007). The impact of sport-hunting on the population dynamics of an African lion population in a protected area. Biological Conservation 134: $548-558$

Lucherini M, Birochio D, Luengos Vidal E, Merino MJ, Soler L (2003). Linking Education and Research for the Conservation of the Andean Mountain Cat. Bahia Blanca, BP Conservation Education Program.

Lucherini M, de Oliveira T, Acosta G (2008). Leopardus geoffroyi. In IUCN Red List of Threatened Species. Version 2011.1. http://www.iucnredlist.org.

Macdonald DW (2009). The Encyclopedia of Mammals. Oxford, Oxford University Press.

Macdonald DW, Burnham D (eds.) (2011). Focus on Felids. Oxford, WildCRU Wildlife Conservation Research Unit.

Macdonald DW, Loveridge AJ (2010). The Biology and Conservation of Wild Felids Oxford, Oxford University Press.

Macdonald DW, Sillero-Zubiri C (2004). Conservation. In The Biology and Conservation of Wild Canids (Macdonald DW, Sillero-Zubiri C, eds.), pp 353-372. Oxford, Oxford University Press.

Macdonald DW, Boitani L, Dinerstein E, Fritz H, Wrangham R (2013). Conserving large mammals: are they a special case? In Key Topics in Conservation Biology, vol. 2 (Macdonald DW, Willis KJ, eds.). Oxford, Wiley-Blackwell.

Macdonald DW, Loveridge AJ, Rabinowitz AR (2010a). Felid futures: crossing disciplines, borders, and generations. In Biology and Conservation of Wild Felids (Macdonald DW, Loveridge AJ, eds.), pp 599-649. Oxford, Oxford University Press.

Macdonald DW, Yamaguchi N, Kitchener AC, Daniels M, Kilshaw K, Driscoll C (2010b). Reversing cryptic extinction: the history, present, and future of the Scottish wildcat. In Biology and Conservation of Wild Felids (Macdonald DW, Loveridge AJ, eds.), pp 471-492. Oxford, Oxford University Press.

Macdonald EA, Collins M, Johnson PJ, Clayton LM, Malhi Y, Fisher JB, Milner-Gulland EJ, Macdonald DW (2011). Wildlife conservation and reduced emissions from deforestation in a case study of Nantu National Park, Sulawesi. 1. The effectiveness of forest protection - many measures, one goal. Environmental Science and Policy 14: 697-708.

Mace GG, Possingham HP, Leader-Williams N (2006). Prioritizing choices in conservation. In Key Topics in Conservation (Macdonald DW, Service K, eds.). Oxford, Wiley-Blackwell.

Maclennan SD, Groom RJ, Macdonald DW, Frank LG (2009). Evaluation of a compensation scheme to bring about pastoralist tolerance of lions. Biological Conservation 142: 2419-2427.

Marchini S, Macdonald DW (2012). Predicting ranchers' intention to kill jaguars: case studies in Amazonia and Pantanal. Biological Conservation 147: 213-221.

Marker L, Dickman AJ, Mills MGL, Macdonald DW (2010). Cheetahs and ranchers in Namibia: a case study. In Biology and Conservation of Wild Felids (Macdonald DW, Loveridge AJ, eds.), pp 353372. Oxford, Oxford University Press.

Marsh LK, Cuarón AD, Cortés-Ortiz L, Shedden A, Rodríguez-Luna E, de Grammont PC (2008). Alouatta pigra. In IUCN Red List of Threatened Species. Version 2011.2. http://www.iucnredlist.org.

- McGraw SW (2005). Update on the search for Miss Waldron's red colobus monkey. International Journal of Primatology 26: 605-619.

Mendelssohn H (1989). Felids in Israel. Cat News 10: 2-4.

Mendes SL, de Oliveira MM, Mittermeier RA, Rylands AB (2008). Brachyteles hypoxanthus. In IUCN Red List of Threatened Species. Version 2011.1. http://www.iucnredlist.org.

Miller DJ, Jackson R (1994). Livestock and snow leopards: making room for competing users on the Tibetan Plateau. In Proceedings of the Seventh International Snow Leopard Symposium (Fox JL, Jizeng D, eds.). Seattle, International Snow Leopard Trust.

Mittermeier RA, Konstant WR, Nicoll ME, Langrand O (1992). Lemurs of Madagascar: An Action Plan for Their Conservation. 1993-1999. Gland, IUCN/SSC Primate Specialist Group

Mittermeier RA, Wallis J, Rylands AB, Ganzhorn JU, Oates JF, Williamson EA, Palacios E, Heymann EW, Kierulff MCM, Yongcheng L, Supriatna J, Roos C, Walker S, Cortés-Ortiz L, Schwitzer C (2009). Primates in peril: The world's 25 most endangered primates 2008-2010. Primate Conservation $24: 1-57$ 
Mohd-Azlan J, Sanderson J (2007). Geographic distribution and conservation status of the bay cat $\mathrm{Ca}$ topuma badia, a Bornean endemic. Oryx 41: 394-397.

Mukherjee S, Sanderson J, Duckworth W, Melisch R, Khan J, Wilting A, Sunarto S, Howard JG (2010). Prionailurus viverrinus. In IUCN Red List of Threatened Species. Version 2011.1. http://www. iucnredlist.org.

Munson L, Terio KA, Ryser-Degiorgis M-P, Lane EP, Courchamp F (2010). Wild felid diseases: conservation implications and management strategies. In Biology and Conservation of Wild Felids (Macdonald DW, Loveridge AJ, eds.), pp 237-262. Oxford, Oxford University Press.

Murdoch JD, Munkhzul T, Reading RP (2006). Pallas' cat ecology and conservation in the semi-desert steppes of Mongolia. Cat News 45: 18-19.

Nadler T, Xuan Canh L, Ngoc Thanh V, Khac Quyet L (2008). Trachypithecus delacouri. In IUCN Red List of Threatened Species. Version 2011.1. http://www.iucnredlist.org.

Nekaris A, Shekelle M (2008). Nycticebus javanicus. In IUCN Red List of Threatened Species. Version 2011.1. http://www.iucnredlist.org.

Nekaris KAI (2003). Distribution and behaviour of three small wild cats in Sri Lanka. Cat News 38: $30-32$.

Ngoc Thanh V, Lippold L, Nadler T, Timmins RJ (2008). Pygathrix cinerea. In IUCN Red List of Threatened Species. Version 2011.1. http://www.iucnredlist.org.

Nijman V, Hon J, Richardson M (2008). Presbytis chrysomelas. In IUCN Red List of Threatened Species. Version 2011.1. http://www.iucnredlist.org.

Nowell K (2007). Asian Big Cat Conservation and Trade Control in Selected Range States: Evaluating Implementation and Effectiveness of CITES Recommendations. Cambridge, TRAFFIC International.

Nowell K (2008). Lynx canadensis. In IUCN Red List of Threatened Species. Version 2011.1. http://www. iucnredlist.org.

Nowell K, Jackson P (1996). Wild Cats. Status Survey and Conservation Action Plan. Gland, IUCN/SSC Cat Specialist Group.

Oates J, Sunderland-Groves J, Bergl R, Dunn A, Nicholas A, Takang E, Omeni F, Imong I, Fotso R, Nkembi L, Williamson L (2007). Regional Action Plan for the Conservation of the Cross River Gorilla (Gorilla gorilla diehli). Arlington, IUCN/SSC Primate Specialist Group and Conservation International.

Oates JF (1996). African Primates: Status Survey and Conservation Action Plan, rev ed. Gland, IUCN/ SSC Primate Specialist Group.

Oates JF (2011). Primates of West Africa: A Field Guide and Natural History. Arlington, Conservation International.

Oates JF, Bearder SK (2008). Cercopithecus solatus. In IUCN Red List of Threatened Species Version 2011.1. http://www.iucnredlist.org.

Oates JF, Butynski TM (2008a). Mandrillus leucophaeus. In IUCN Red List of Threatened Species. Version 2011.1. http://www.iucnredlist.org.

Oates JF, Butynski TM (2008b). Mandrillus sphinx. In IUCN Red List of Threatened Species. Version 2011.1. http://www.iucnredlist.org.

Oates JF, Bergl RA, Sunderland-Groves J, Dunn A (2008a). Gorilla gorilla ssp. diehli. In IUCN Red List of Threatened Species. Version 2011.1. http://www.iucnredlist.org.

Oates JF, Gippoliti S, Groves CP (2008b). Cercopithecus diana. In IUCN Red List of Threatened Species. Version 2011.1. http://www.iucnredlist.org.

Oates JF, Struhsaker T, McGraw S (2008c). Procolobus badius ssp. waldroni. In IUCN Red List of Threatened Species. Version 2011.2. http://www.iucnredlist.org.

Oates JF, Struhsaker T, Morgan B, Linder J, Ting N (2008d). Procolobus preussi. In IUCN Red List of Threatened Species. Version 2011.1. http://www.iucnredlist.org.

Oates JF, Tutin CEG, Humle T, Wilson ML, Baillie JEM, Balmforth Z, Blom A, Boesch C, Cox D, Davenport T, Dunn A, Dupain J, Duvall C, Ellis CM, Farmer KH, Gatti S, Greengrass E, Hart J, Herbinger I, Hicks C, Hunt KD, Kamenya S, Maisels F, Mitani JC, Moore J, Morgan BJ, Morgan DB, Nakamura M, Nixon S, Plumptre AJ, Reynolds V, Stokes EJ, Walsh PD (2008e). Pan troglodytes. In IUCN Red List of Threatened Species. Version 2011.1. http://www.iucnredlist.org.

Prescott GW, Johnson PJ, Loveridge AJ, Macdonald DW (2012). Does change in IUCN status affect demand for African bovid trophies? Animal Conservation 15: 248-252.

Pulliainen E (1992). From extinction to real lynx life: Finnish experiences In The Situation, Conservation Needs and Reintroduction of Lynx in Europe. Proc. Symp. 17-19 October, Neuchatel, Switzerland, Environmental Encounters No. 11, pp 17-18. Strasbourg, Council of Europe Press.

Pullin AS, Stewart GB (2006). Guidelines for systematic review in conservation and environmental management. Conservation Biology 20: 1647-1656.

R-version-2.13.1 (2011). The R Foundation for Statistical Computing. Platform: i386-pc-mingw32/i386 (32-bit) (accessed August 7, 2011). 
Rabinowitz A (2005). Jaguars and livestock: living with the world's third largest cat. In People and Wildlife: Conflict or Coexistence? (Woodroffe R, Thirgood S, Rabinowitz A, eds.), pp 278-285. Cambridge, Cambridge University Press.

Rabinowitz AR (2007). Connecting the dots: saving a species throughout its range. In Felid Biology and Conservation Conference 17-20 September: Abstracts (Hughes J, Mercer R, eds.), p 61. Oxford, WildCRU Wildlife Conservation Research Unit.

Rautner M (2005). Borneo: Treasure Island at Risk. Frankfurt, WWF Germany.

Reynolds V (2005). The Chimpanzees of the Budongo Forest: Ecology, Behaviour, and Conservation. Oxford, Oxford University Press.

Reza A, Feeroz M, Islam M (2001). Food habits of the Bengal tiger (Panthera tigris tigris) in the Sundarbans. Bangladesh Journal of Zoology 29: 173-179.

Rithe K (2011). Melghat's new lease of life. Sanctuary Asia, October, pp 48-51.

Roberts PD, Steward GB, Pullin AS (2006). Are review articles a reliable source of evidence to support conservation and environmental management? A comparison with medicine. Biological Conservation 132: 409-423.

Rodrigues ASL, Akcakaya HR, Andelman SJ, Bakarr MI, Boitani L, Brooks TM, Chanson JS, Fishpool LDC, Da Fonseca GAB, Gaston KJ, Hoffmann M, Marquet PA, Pilgrim JD, Pressey RL, Schipper J, Sechrest W, Stuart SN, Underhill LG, Waller RW, Watts MEJ, Yan X (2004). Global gap analysis: Priority regions for expanding the global protected-area network. Bioscience 54: 1092-1100.

Ross S, Murdoch J, Mallon D, Sanderson J, Barashkova A (2008). Otocolobus manul. In IUCN Red List of Threatened Species. Version 2011.1. http://www.iucnredlist.org.

- Sandbrook C, Semple S (2006). The rules and the reality of mountain gorilla Gorilla beringei beringei tracking: how close do tourists get? Oryx 40: 428-433.

-Sanderson EW, Redford KH, Chetkiewicz C-LB, Medellin RA, Rabinowitz AR, Robinson JG, Taber AB (2002). Planning to save a species: the jaguar as a model. Conservation Biology 16: 58-72.

Sanderson J, Khan JA, Grassman L, Mallon DP (2008a). Neofelis nebulosa. In IUCN Red List of Threatened Species. Version 2011.1. http://www.iucnredlist.org.

Sanderson J, Mukherjee S, Wilting A, Sunarto S, Hearn A, Ross J, Khan JA (2008b). Pardofelis temminckii. In IUCN Red List of Threatened Species. Version 2011.1. http://www.iucnredlist.org.

- Sankar K, Johnsingh AJT (2002). Food habits of tiger (Panthera tigris) and leopard (Panthera pardus) in Sariska Tiger Reserve, Rajasthan, India, as shown by scat analysis. Mammalia 66: 285-289.

Savage A, Causado J (2008). Saguinus oedipus. In IUCN Red List of Threatened Species. Version 2011.1. http://www.iucnredlist.org.

Schaller GB, Tserendeleg J, Amarsanaa G (1994). Observations on snow leopards in Mongolia. In Proceedings of the Seventh International Snow Leopard Symposium (Fox JL, Jizeng D, eds.). Seattle, International Snow Leopard Trust.

- Seidensticker J (1983). Predation by Panthera cats and measures of human influence in habitats of South Asian monkeys. International Journal of Primatology 4: 323-326.

Seidensticker J, Syuono I (1980). The Javan Tiger and the Meru-Betiri Reserve: A Plan for Management. Gland, IUCN, p 167.

Shekelle M, Salim A (2010). Tarsius tumpara. In IUCN Red List of Threatened Species. Version 2011.1. http://www.iucnredlist.org.

Singleton I, Wich SA, Griffiths M (2008). Pongo abelii. In IUCN Red List of Threatened Species. Version 2011.1. http://www.iucnredlist.org.

Smith AT, Formozov NA, Hoffmann RS, Zheng C-L, Erbajeva. MA (1990). The pikas. In Rabbits, Hares and Pikas: Status Survey and Conservation Action Plan (Chapman JA, Flux JEC, eds.), pp 14-60. Gland, IUCN.

Srivastava KK, Bharadwa AK, Abraham C, Zacharias VJ (1996). Food habitats of mammalian predators in Periyar Tiger Reserve, South India. Indian Forester 122: 877-883.

Stevenson P, Link A (2008). Lagothrix lugens. In IUCN Red List of Threatened Species. Version 2011.1. http://www.iucnredlist.org.

Struhsaker T, Butynski TM, Ehardt C (2008). Procolobus gordonorum. In IUCN Red List of Threatened Species. Version 2011.1. http://www.iucnredlist.org.

Struhsaker T, Siex K (2008). Procolobus kirkii. In IUCN Red List of Threatened Species. Version 2011.1. http://www.iucnredlist.org.

- Summers DM, Bryan BA, Crossman ND, Meyer WS (2012). Species vulnerability to climate change: impacts on spatial conservation priorities and species representation. Global Change Biology 18: $2335-2348$.

Sunquist M, Sunquist F (2002). Wild Cats of the World. Chicago, University of Chicago Press.

Supriatna J, Andayani N (2008). Macaca nigra. In IUCN Red List of Threatened Species. Version 2011.1. http://www.iucnredlist.org.

- Sutherland WJ, Pullin AS, Dolman PM, Knight TM (2004). The need for evidence-based conservation. Trends in Ecology and Evolution 19: 305-308. 
Theile S (2003). Fading Footprints: The Killing and Trade of Snow Leopards. Cambridge, TRAFFIC International.

Urbani B, Morales AL, Link A, Stevenson P (2008). Ateles hybridus. In IUCN Red List of Threatened Species. Version 2011.1. http://www.iucnredlist.org.

Veiga L, Bóveda-Penalba A, Vermeer J, Tello-Alvarado JC, Cornejo F (2011). Callicebus oenanthe. In IUCN Red List of Threatened Species. Version 2011.1. http://www.iucnredlist.org.

Veiga LM, Printes RC, Rylands AB, Kierulff CM, de Oliveira MM, Mendes SL (2008a). Callicebus barbarabrownae. In IUCN Red List of Threatened Species. Version 2011.1. http://www.iucnredlist. org.

Veiga LM, Silva JS Jr, Ferrari SF, Rylands AB (2008b). Chiropotes satanas. In IUCN Red List of Threatened Species. Version 2011.1. http://www.iucnredlist.org.

Villalba L, Lucherini M, Walker S, Cossíos D, Iriarte A, Sanderson J, Gallardo G, Alfaro F, Napolitano C, Sillero-Zubiri C (2004). The Andean Cat: Conservation Action Plan. La Paz, Andean Cat Alliance.

Villalba ML, Bernal N, Nowell K, Macdonald DW (2012). Distribution of two Andean small cats (Leopardus jacobita and Leopardus colocolo) in Bolivia and the potential impacts of traditional beliefs on their conservation. Endangered Species Research 16: 85-94.

Von Arx M, Breitenmoser-Wursten C (2008). Lynx pardinus. In IUCN Red List of Threatened Species. Version 2011.1. http://www.iucnredlist.org.

Walsh PD (2013). Disease control. In Key Topics in Conservation Biology, vol. 2 (Macdonald DW, Willis KJ, eds.). Oxford, Wiley-Blackwell.

Walsh PD, Biek R, Real LA (2005). Wave-like spread of Ebola Zaire. Plos Biology 3: 1946-1953.

-Wang SW, Macdonald DW (2006). Livestock predation by carnivores in Jigme Singye Wangchuck National Park, Bhutan. Biological Conservation 129: 558-565.

Werre JLR (2000). Ecology and Behavior of the Niger Delta Red Colobus Monkey (Procolobus badius epieni). PhD thesis, City University of New York.

-Whittaker D (2006). A conservation action plan for the Mentawai primates. Primate Conservation 20: 95-105.

Whittaker D, Mittermeier RA (2008). Macaca pagensis. In IUCN Red List of Threatened Species. Version 2011.1. http://www.iucnredlist.org.

Wildt D, Swanson W, Brown J, Silwa A, Vargas A (2010). Felids ex situ: Managed programmes, research, and species recovery. In Biology and Conservation of Wild Felids (Macdonald DW, Loveridge AJ, eds.), pp 217-236. Oxford, Oxford University Press.

Wilting A, Cord A, Hearn AJ, Hesse D, Mohamed A (2010). Modelling the species distribution of flatheaded cats (Prionailurus planiceps), an endangered South-East Asian small felid. PLoS One 5(3): e9612. doi: 10.1371/journal.pone.0009612.

Wingard JR, Zahler P (2006). Silent Steppe: The Illegal Wildlife Trade Crisis in Mongolia. Mongolia Discussion Papers. Washington, World Bank, East Asia and Pacific Environment and Social Development Department.

Wrangham RW (2000). The snare patrol. Natural History 109: 46.

Wrangham RW, Goldberg TL (1997). An overview of chimpanzee conservation and management strategies. In Conserving the Chimpanzees of Uganda: Population and Habitat Viability Assessment for Pan troglodytes schweinfurthii (Edroma E, Rosen N, Miller P, eds.), pp 156-162. Entebbe, IUCN/ SSC Conservation Breeding Specialist Group.

Zommers Z, Macdonald DW (2012). Protected areas as frontiers for migration. Conservation Biology 26: 547-556. 